\title{
Economic Cycles and Stock Return Volatility: Evidence from the Past Two Decades
}

\author{
Benedicto K. Lukanima ${ }^{1}$ \& Raymond Swaray ${ }^{2}$ \\ ${ }^{1}$ Business School, Universidad Del Norte, Colombia \\ ${ }^{2}$ Business School, The University of Hull, United Kingdom \\ Correspondence: Dr. Benedicto K. Lukanima, Cr 52 85-19, Barranquilla, Colombia. Tel: 57-30-4430-5335. \\ E-mail: blukanima@uninorte.edu.co
}

Received: April 4, 2013

Accepted: May 16, 2013

Online Published: June 20, 2013

doi:10.5539/ijef.v5n7p50

URL: http://dx.doi.org/10.5539/ijef.v5n7p50

\begin{abstract}
We use EGARCH-M models to examine the co-cyclical nature of stock returns in relation to economic cycles, focusing on three key variables, namely stock return volatility, risk premium and information asymmetry. We incorporate a wider and systematic alley of major global economic events since 1990s to the end of 2011. The main objective is to provide a corroborative evidence of the cyclicality nature of stock return volatility in the global context, and to present a consolidated volatility alley in association with major economic events. The overall conclusion is that increases in stock returns during good economic conditions tend to be associated with increases in risk premium, but decreases in overall risk and the impact of bad news (information asymmetry), and increase or decrease in volatility persistent. It is the vice versa during bad times. This conclusion emphasizes findings from previous studies, while providing new intuitions for stimulating more debate on the nature of contradictions from previous studies. Also, our findings have significant implications for investors and decision-makers at corporate, national, and international levels.
\end{abstract}

Keywords: economic cycles, stock returns, volatility, risk premium, asymmetry, E-GARCH

\section{Introduction}

Economic studies suggest a strong relationship between stock market volatility and other economic factors (Modiglian \& Cohn, 1979; Fama, 1981; Hamilton \& Lin, 1996). Schwertz (1989b) shows that stock market volatility changed over time, relative to changes in economic variables between 1848 and 1987. Also, since the stock market crash of October 1987, studies on stock market behavior show evidence of systematic behavioral change in global stock markets over time in relation to global economic cycles (e.g. Kasa, 1992; Jorion \& Goetzmann, 1999; Sarantis, 2001; Beck \& Levine, 2004; Beltratti \& Morana, 2006), persistent global imbalances, domestic market structures and stock market reforms (Gonzales, Spencer \& Walz, 2003; Basher, Hassan \& Islam, 2007); and behavioral aspects like rational expectations on dividend and interest rates (Shiller, 1981; Nasseh \& Strauss, 2004; Cunado, Gil-Alana \& Perez De Gracia, 2005). Therefore, as pointed out by Harvey (1989), stock markets can play a significant role in forecasting economic performance. A fall or a rise in stock indices may indicate a weak or a sound economic prospect respectively.

Apart from the cyclical behavioral change in individual stock markets, there is also evidence on the integration and correlation of global stock markets. The linkage between markets has been addressed categorically in relation to such issues like the contagion phenomenon (King \& Wadhwani, 1990; Caporale, Cipollin \& Spagnolo, 2005), time-variation in the covariance between stock markets and the extent of market integration (Bae \& Karolyi, 1994; King, Sentana \& Wadhwani, 1994; Bekaert \& Harvey, 1995; Longin \& Solnik, 1995), and volatility transmission between markets both within countries (Frank, Gonzales \& Hesse, 2008) and across global markets (Ng, 2000; Bartram \& Wang, 2005). In particular, some studies focus on markets' response to global economic shocks like the 1997 Asian economic crisis (Forbes \& Rigobon, 2002; Bekaert, Harvey \& Ng, 2005; Corsetti, Pericoli \& Sbracia, 2005; Caporale, Pittid \& Spagnolo, 2006) and the 2007 financial crisis (Beirne, Caporale, Schulze \& Spagnolo, 2009; Frank \& Hesse, 2009). Overall, these studies suggest that during crises cross-market correlations increases, asset prices drop largely, alongside increase in market volatility.

More specifically, Schwert (1989b), using monthly stock returns in USA markets (Dow Jones and Standard and 
Poor's) show highly persistent increases in stock return volatility during the Great Depression (1929-1939). In a contradicting way, he also suggests "volatility increases after major financial crises" (Schwert, 1989a). Recently, he suggests increases in volatility in USA stocks during the recent global crisis of 2008 (Schwert, 2011). Comparatively, he comments that whereas volatility during the Great Depression prolonged for a long time, it appears to be short-lived during the recent global crisis. Campbell (1992) comments "volatility is typically higher after the stock market fall than after it rises". This is consistent with Black (1976), contending that stock price volatility tend to increase after stock prices decline, suggesting a leverage effect or information asymmetry. Indeed, most empirical evidences show that bad news tend to trigger higher volatility than positive news. Especially, in financial markets, downward price movements are often followed by higher volatility than upward movements of the same magnitude (French, Schwert \& Stambaugh, 1987; Bekaert \& Wu, 2000; Mele, 2007). The cyclical behavior of stock markets has also been investigated in relation to risk premium, referring to the trade-off between risk and return, according to CAPM (Sharpe, 1964). Stock market risk and the resultant risk premium are driven by several factors, both domestic and international, including investors' risk behavior (Chan, Karolyi \& Stulz, 1992).

From these studies, four contradicting issues emerge. Firstly, it is unclear whether stock volatility actually increases "during" or "after" bad economic conditions. Secondly, regarding leverage effects, "bad news" and "bad times" are two phenomena that require a clear distinction. That is, news (either bad or good) can be available within any time period (bad or good); hence an increase in volatility due to bad news is not the same as increase in volatility due to a bad economic condition. Usually, response to news tends to be instantaneous and relatively short-lived, while the effects of economic conditions (like recessions, expansions or booms) tend to last over a relatively long period. Therefore, it is important to show the extent of leverage effects in bad times and in good times. Thirdly, although there is a general agreement that investors (within a given time period) expect larger return from a riskier security, evidence on the validity of risk-return trade-off (CAPM hypothesis) is mixed: with several opponents (Markowitz, 1959; Lintner, 1965; Campbell, 1992) and proponents (Chan, Hamao \& Lakonishok, 1991; Nelson, 1991; Glosten, Jarannathan \& Runkle, 1993; Brandt \& Kang, 2004).

This study, therefore, addresses these issues by incorporating a wider and systematic alley of major global economic events since 1990s to the end of 2011. Moreover, unlike most of the previous studies, we relate the four volatility aspects (namely risk premium, information asymmetry, persistence, and conditional volatility) for a large number of stock returns globally. The main objective is to provide a corroborative evidence of the cyclicality nature of stock return volatility in the global context, and present a consolidated volatility alley in association with major economic events. Our approach is based on EGARCH-M models for daily stock returns. Specifically, we define eight major events that dominated the global economy over the past two decades, namely: pre Asian Crisis (1990-1997), the Asian economic crisis (1997-1999), post Asian economic crisis: economic recovery (1999-2002), Global economic boom (2003-2007), pre global financial crisis (2007-2008), the global financial crisis (2008-2009), post global financial crisis: economic recovery (2009-2010), and the Greece debt crisis (2010-2011).

Our key findings emphasize some of the previous findings, contradicting others, while providing new intuitions for elaborating the nature of contradictions from previous studies. Firstly, we find mixed evidence on the risk-return trade-off, in which some of the stock returns appear not to carry the risk premia. Overall, despite differences in the risk compensation content, favorable economic conditions (like recovery and boom) appear to correspond to improved risk premia in most markets. Secondly, volatility asymmetry is evident in both bad and good times. But, the responsiveness of leverage effects tend to differ across stock markets, with a tendency of asymmetric co-movement along the economic cycles; in which bad news tend to increase more volatility than good news during bad times (like recession and crises). Thirdly, we find mixed results on volatility persistent: in some markets, persistence in stock returns tends to decrease during bad economic conditions, while increase during good times. It is the contrary in some markets. In addition, based on standard deviations, we find that, on average, volatility tends to increase "during" (rather than "after") bad times, alongside a drop in stock returns. Eventually, we consistently corroborate previous studies that stock return volatility is cyclically corresponding to economic cycles.

The remainder of the paper is organized as follows. Section 2 explains the economic cycles by providing a brief overview of the major economic events since 1990s. Section 3 gives a description of the model and data. Empirical results are presented and discussed in section 4 , whereas section 5 gives a brief conclusion.

\section{A Brief Overview of Economic Cycles since 1990}

The 1990s corresponds to the period in which many countries adopted a series of financial sector liberalization 
measures, which started early in 1980s, aimed at increasing market integration. Among other things, these measures included interest rate liberalization, market entry deregulations, reduction of reserve requirements and removal of credit allocation, sharp reductions in direct credit allocations, curtailing the role of state-owned banks while simultaneously stimulating entry by foreign financial institutions. In many emerging markets, these measures increased short-term capital inflows and helped them to finance imports, provide credit to the private sector, pay external debt, and improve the overall economic growth. However, these benefits came at the cost of increasing the countries' exposure to economic vulnerability (Eichengreen, 1999; Rodrik, 1999). According to Stiglitz (1999), the market liberalization process had shortfalls because it did not take into account the design and execution of regulation structures appropriate to the circumstances: it was based more in ideology than in economic science.

The Asian economic crisis started in 1997. Among other factors, this crisis is said to be triggered by such factors as: the enormous weight taken by short-term financial capital in the financial structure of emerging markets, following the preceding IMF global liberalization policies and pressure from the US (Stiglitz, 2000); weak corporate governance, in association with variables like information disclosure, insider dealings, and corruption (Radelet, Sachs, Cooper \& Bosworth, 1998; Mitton, 2002); and ownership structure and diversification (Mitton, 2002). In turn, several financial aspects were affected: for example, replacement of prudential supervision with risk pricing, rise of derivative assets with opaque markets and few players, replacement of bank loans with bonds, and so on. Overall, the Asian financial crisis involved four basic aspects: (1) a shortage of foreign exchange that caused the value of currencies and equities in Thailand, Indonesia, South Korea and other Asian countries to fall dramatically, (2) inadequately developed financial sectors and mechanisms for allocating capital in the troubled Asian economies, (3) effects of the crisis on both the United States and the world, and (4) the role, operations, and replenishment of funds of the International Monetary Fund.

The economic recession that was caused by the 1997 crisis lasted until 2002. Between 2003 and 2007, many countries experienced economic boom as a result of four major factors: high commodity prices, booming international trade, exceptional financing conditions, and high levels of remittances (Griffith-Jones \& Ocampo, 2009). During the same period, stock markets experienced a bull market. These factors started to reverse between 2007 and mid-2008, but the rate of their deterioration was further accelerated by the world financial meltdown from September 2008, which resulted from the US housing bubble. Like the previous crises, the global financial crisis caused considerable economic slowdown globally. The immediately observed effects included the plunging of stock markets and collapse of some investment banks.

There is no a clear-cut date for the end of the global financial crisis. But most stock markets indices (e.g. the S\&P 500 index and the Dow Jones Industrial Average (DJIA)) rebounded by the March 2009. Overall, 2009 was practically a great year for all global indices especially equities and bonds which rebounded strongly from an abysmal level in 2008. From this rebound the recovery process started gradually. This can be explained by momentous victory for investors by the end of 2009. For example, the DJIA rose by $59.3 \%$ from its March 9 close, and the S\&P 500 rose by $64.8 \%$. For the entire 12 -month period, the S\&P closed the year up $23.45 \%$, and the DJIA closed up $18.82 \%$.

The Greece debt crisis, which was revealed in early 2010 has triggers economic chaos all over Europe and globally. It was revealed that successive Greek governments had been found to have consistently and deliberately misreported the country's official economic statistics to keep within the Monetary Union Guidelines. But the degree of fear on the crisis was evidence in May 2010, when the Greek government deficit was again revised and estimated to be $13.6 \%$ for the year, which was one of the highest in the world relative to GDP. Total public debt was forecast, according to some estimates, to hit $120 \%$ of GDP during 2010. Since then, there has been a crisis in international confidence in Greece's ability to repay its sovereign debt. Despite several rescue efforts, the crisis has been widely spreading to other European countries.

\section{Model and Data Description}

We employ an EGARCH-M, a class of ARCH-type volatility models pioneered by Engle (1982) and Bollerslev (1986). The superiority of these models is mainly based on their ability to allow the conditional variance to vary over-time and capture excess kurtosis available in most financial assets. Founded on the essence of capturing information asymmetry in volatility, the EGARCH model (Nelson, 1991) has several advantages over the standard GARCH model. Particularly, in the EGARCH model, the effect of recent residuals is exponential rather than quadratic, and does not require imposing non-negativity restriction in the value of GARCH parameters. The mean equation with a simple constant can be specified as: 


$$
\log R_{t}=\mu+\varepsilon_{t} ; \quad \varepsilon_{t} \mid \Omega_{t-1} \approx\left(0, h_{t}\right)
$$

While the variance equation can be expressed as:

$$
\log \left(h_{t}^{2}\right)=\omega+\pi_{1}\left|\frac{\varepsilon_{t-1}}{\sqrt{h_{t-1}^{2}}}\right|+\pi_{2} \frac{\varepsilon_{t-1}}{\sqrt{h_{t-1}^{2}}}+\beta \log \left(h_{t-1}^{2}\right)
$$

In the mean equation (1), $R_{t}$ denotes the daily stock returns; $\varepsilon_{t}$ is the error term, which is assumed to be normally distributed with zero mean and variance $h_{t} ; \Omega_{t-1}$ represents random information set available at time $t-1$. Equation (2) allows good news and bad news to have a different impact on volatility because the level of $\varepsilon_{t-1} / h_{t-1}$ are included with a coefficient $\pi_{2}$ for capturing asymmetry volatility. If $\pi_{2}=0$, a positive shock and a negative shock of the same magnitude have the same effect on volatility. If $-1<\pi_{2}<0$, a negative shock increases volatility more than a positive shock. Thus, if $\pi_{2}>0$, positive shocks cause higher volatility than negative shocks, and vice versa. $\pi_{1}$ explains the magnitude of the conditional shock on the conditional variance. EGARCH provides an oscillatory behavior in the conditional variance since $\beta$, a measure of volatility persistence, can be either negative or positive. Stationarity and ergodicity for the EGARCH model is ensured with $|\beta|<1$ : the smaller the absolute value of $\beta$, the less the volatility persistence after a shock.

To measure risk premium, we follow Engle, Lilien \& Robins (1987) by augmenting the variance in the mean equation. In this procedure the expected return on stocks is related to the expected risk. Thus, the mean equation becomes:

$$
\log R_{t}=\mu+\lambda h_{t}^{2}+\varepsilon_{t} ; \quad \varepsilon_{t} \mid \Omega_{t-1} \approx\left(0, h_{t}\right)
$$

where $\lambda$ denotes estimation coefficient reflecting a risk premium with respect to the conditional variance of stock prices. Thus, if the coefficient for risk premium is positive and statistically significant, stock prices can be considered to carry a risk premium, and vice versa. Other researchers have applied this approach in similar studies (French et al., 1987; Koutmos, Negakis \& Theodossiou, 1993; Rayhorm, Hassan, Yu \& Tanson, 2007; Adrian \& Rosenberg, 2008).

We use daily closing values, $P_{t}$ (without dividends) of 29 stock indices globally, since January 1990 to December 2011, depending on the functioning of the selected stock exchanges (see Appendix A). Data was obtained from Yahoo Finance, which gather stock indices data from different sources, with daily updates provided by Commodity Systems Inc. (CSI). CSI data is also available in bulk on CD-ROM and has gain reputation due to its accuracy, unparalleled scope and longevity. Our analysis uses stock index return $\left(R_{t}=\ln \left(P_{t} / P_{t-1}\right)\right.$, defined as the first log difference of each stock index. Specifically, we categorize the sample periods as: (1) Pre Asian financial crisis, (2) during the 1997 Asian financial crisis, (3) post Asian crisis: economic recovery, (4) global economic boom, (5) pre global financial crisis (6) during the global financial crisis, (7) post global financial crisis: recovery, (8) Greece debt crisis

Figure 1 and Figure 2 depict the standard deviations and means of stock returns in natural logs, respectively (See Appendix B and C). It is clear that, with very few exceptions, global stocks followed an identical volatility alley. The overall observation is that the decrease in returns during bad times tends to aligned with increase in volatility, while the increases in returns during good times seems to be associated with the decrease in volatility. There are, however, some exceptions, in which some of the stock returns continued to increase during the Asian crisis (1997-1999), especially in Europe and America (except IBOVESPA Brazil). Moreover, the highest peak regarding volatility is evident in the two major crises: the Asian economic crisis (1997-1999) and the global financial crisis (2008-2009). 
American

Markets

Asian and

Australian

Markets

European

Markets

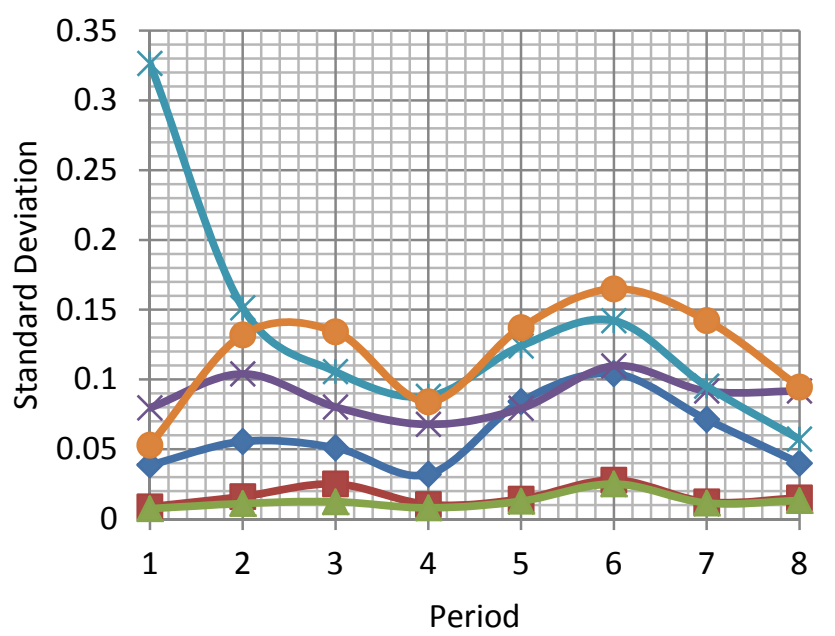

$\longrightarrow$ S\&P 500 USA

$=$ NASDAQ IXIC USA

$\longrightarrow$ DJIA USA

$\longleftarrow$ IPC Mexico

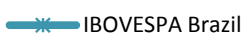

$\longrightarrow$ MERVAL Argentina
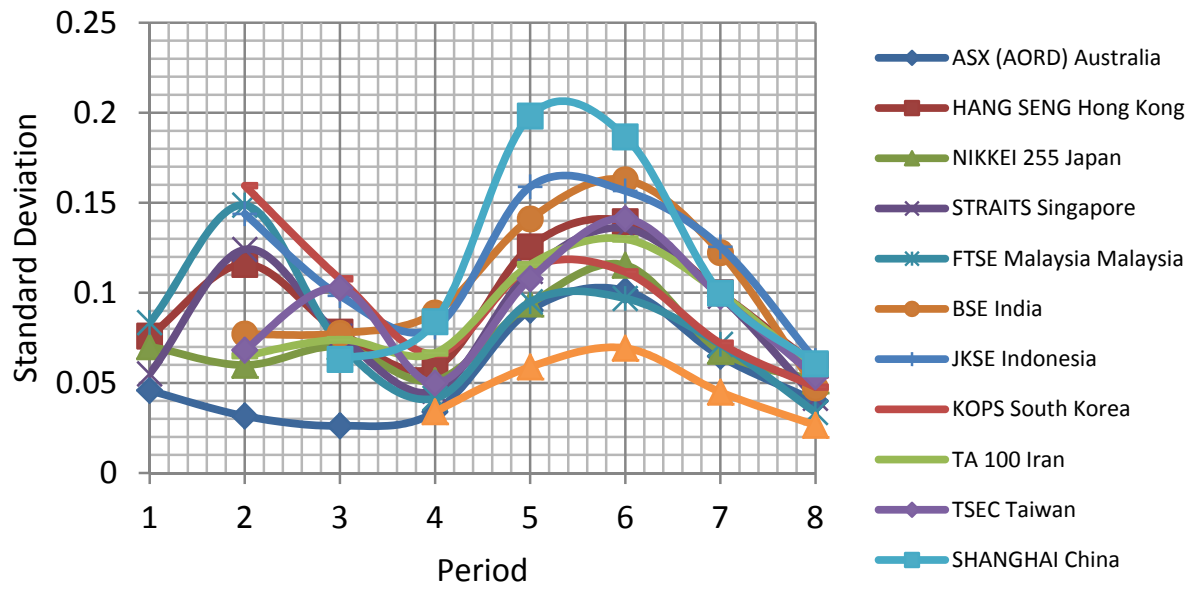

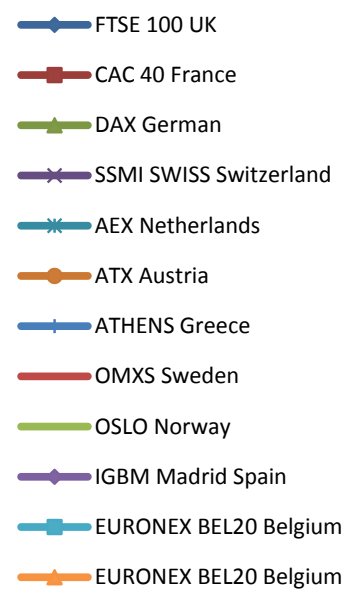

Figure 1. The alley of periodical standard deviation of stock returns 
American

Markets

Asian and

Australian

Markets

European

Markets
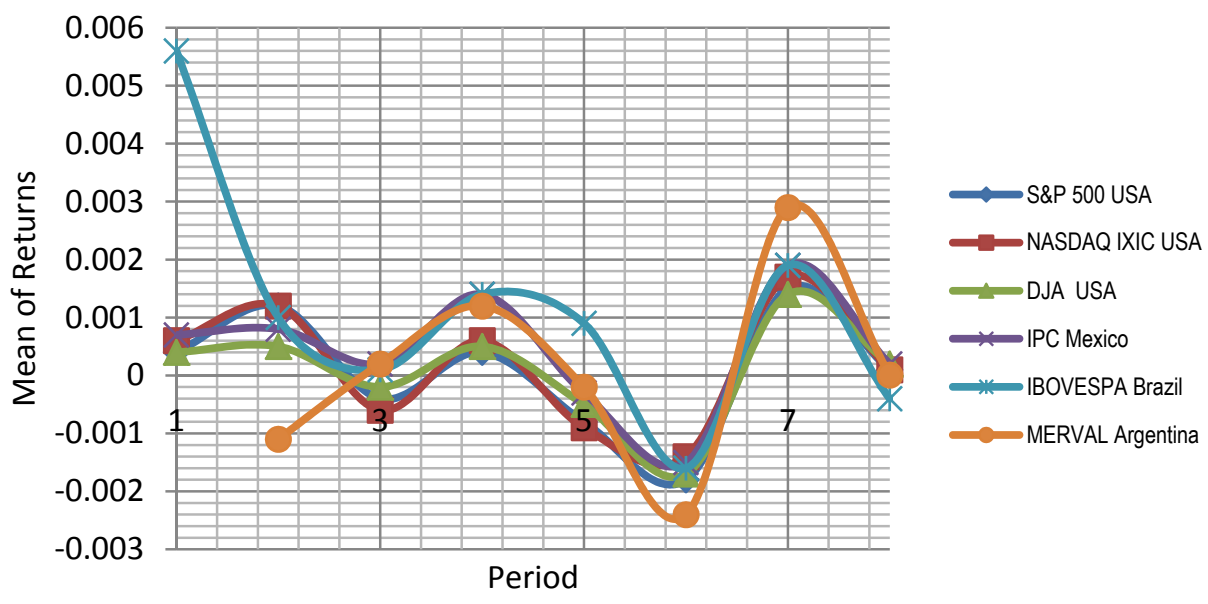

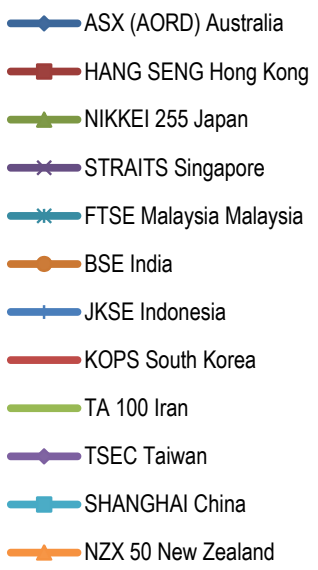

Period
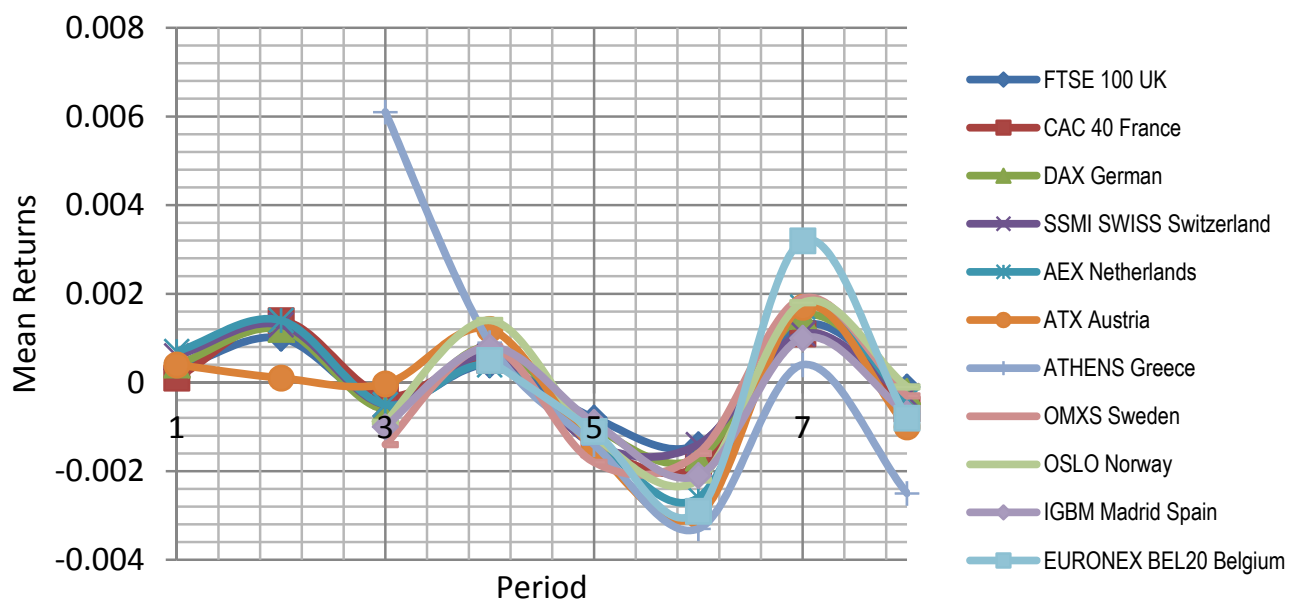

Figure 2. The alley of periodical mean of stock returns 


\section{Empirical Estimates}

\subsection{Estimation Process and Diagnosis}

Estimating GARCH models requires data to be heteroskedastic, which is a stylized fact in daily stock returns (Lamoureux \& Lastrapes, 1990; Campbell, Lettau, Malkiel \& Yu, 2001). Jarque-Bera's normality tests suggested non-normal distribution in almost all stock returns, consistent with previous studies (Anderson, Bollerslev, Diebold \& Ebens, 2001). Unit root tests, using Augmented Dickey Fuller (ADF) and Phillip-Peron (PP) proved stationarity in all series (these tests are not reported, but can be available upon request).

Table 1. Periodical sampling of global economic events since 1990

Description of Economic Condition (January $2^{\text {nd }} 1990$ to December $15^{\text {th }} 2011$ )

Period (1) Pre Asian financial crisis (02/01/1990 - 01/07/1997)

This period can be described as the prelude to the 1997 crisis because the global financial sector reforms (liberalization) that took place during this period are said to have significant contribution to the subsequent crisis in Asia. In this sub-sample, the starting date is based on data span, while the ending date links the beginning of the crisis.

Period (2) The Asian financial crisis (02/07/1997 - 30/03/1999)

The starting date marks the beginning of the crisis in Thailand on 2nd July 1997 with the financial collapse of the Thai Baht following the decision of the Thai government to float the Baht, cutting its peg to the US\$. September 1997 is the months in which we can trace the last Asian country to take domestic policy measures following chronological events in the rescue process, when South Korea lowered its short-term interest rate as real economic activities contracted, while the Russian Government defaulted on its sovereign obligations. Later on the effects of the crisis started to spread globally. But March 1999 is said to mark an end of the crisis and the beginning of the economic recovery.

Period (3) The post Asian economic crisis (01/04/1999 - 31/12/2002)

This period was characterized by economic recovery from the second quarter of 1999 . The switching date is selected because by the end of 2002 most of the countries affected by the Asia crisis had bounced back.

Period (4) The Global Economic Boom (02/01/2003 - 31/07/2007)

This period was not dominated by abnormal financial and economic events. Many countries experienced economic boom as a result of four major factors: high commodity prices, booming international trade, exceptional financing conditions, and high levels of remittances. Following the recovery from the Asian crisis, July 2007 was the boom peak before experiencing economic slump.

Period (5) The pre Global Financial Crisis (01/08/2007 - 16/03/2008)

During this period, factors that contributed to the preceding economic boom started to reverse. This is also a period that includes the beginning of the crisis on U.S. market and shows it effects on the other markets. The switching date links this period with the onset of the 2008 financial crisis.

Period (6) The Global Financial Crisis (17/03/2008 - 31/03/2009)

This period is selected specifically to cover the last fall of stock markets globally. While there are different opinions about the exact date of the onset of the financial crisis, we use March 17th 2008, the date on which US Investment Bank Bear Stearns \& Co collapsed and was taken over by JP Morgan, as the cut-off for our Pre-Crisis/Crisis periods. March 31st 2009 is used as the end date because the S\&P 500 index (and many other stocks) rebounded well from its lowest value by the end of March 2009, followed by persistent rebound in almost all stock and bond markets from an abysmal 2008.

Period (7) The post Crisis: Economic Recovery (01/04/2009 - 30/04/2010)

We consider this as a recovery period because many stock started rebounding in March 2009. For example, the Dow Jones Industrial Average (DJIA) hit a market low of 6,443.27 on March 6, 2009, having lost over 54\% of its value since the October 9, 2007 high. The bear market reversed course on March 9, 2009, as the DJIA rebounded more than 20\% from its low to 7924.56 after a mere three weeks of gains. Also, after March 9, the S\&P 500 was up $30 \%$ by mid May and over $60 \%$ by the end of the year. For the entire 12 -month period, the S\&P closed the year up $23.45 \%$, and the DJIA closed up $18.82 \%$. In this sub-sample, the switching date links the recovery to the beginning of the Greece debt crisis.

Period (8) The Greece Debt Crisis (01/05/ 2010 - 15/12/2011)

In early 2010 it was revealed that successive Greek governments had been found to have consistently and deliberately misreported the country's official economic statistics to keep within the Monetary Union Guidelines. But the degree of fear on the crisis was evidence in May 2010 , when the Greek government deficit was again revised and estimated to be $13.6 \%$ for the year.

Table 1 summarizes the main economic events. In reality, there are no clear-cut points that separate one economic event from another. However, we select switching-point dates that reasonably represent a dominant global economic condition during that specific period.

We estimate a total of 210 EGARCH models with Generalized Error Distribution (GED), using Maximum Likelihood (ML) estimation technique, while maintaining EGARCH-M $(1,1)$ process. Diagnostic tests for autocorrelation in residuals were performed with Lagrange Multiplier (LM-ARCH) for lags 4, 6, and 12, in 
which the estimated models appear to be efficient. In few cases, where residual ARCH tests failed, we estimate the models with normal (Gaussian) and student-t distribution assumptions (see Appendix D). Then, we compared the LM-ARCH tests for both models and selected the model with superior confidence level in the ARCH tests. In order to ensure consistence in covariance and accuracy of standard errors, the models with normality assumptions followed Bollerslev \& Woodridge (1992) for robust standard errors. In certain cases, the normal and student-t assumptions produced relatively consistent diagnostic results. Therefore, Akaike Information Criteria (AIC), Schwartz Information Criteria (SIC), and Hannan-Quinn Information Criteris (HQIC) aided our selection of the appropriate model for making inference.

\subsection{Results and Discussion}

\subsubsection{Risk Premia}

Table 2 presents the coefficients $(\lambda)$ of estimated risk premia from the mean equation (3). Although not all the coefficients are statistically significant, the signs provide implication regarding risk premia during the predominant economic conditions. Coefficients with negative signs imply absence of risk compensation, whereas positive signs suggest the presence of risk compensation in stock returns.

Specifically, before the Asian economic crisis of 1997, some stock returns seem to have carried risk premia: S\&P500, IBOVESPA, ASX (AORD), HANG SENG, NIKKEI255, STRAITS, CAC40, DAX and AEX. But, notable changes occurred in most of the markets during the Asian crisis, in which the risk premia appear to have disappeared in S\&P500, ASX (AORD), HANG SENG, AEX and STRAITS, but emerged in IPC, FTSE100, SSMI SWISS, and ATX. Moreover, during this period, the risk premia dropped in some markets like IBOVESPA (from 6.04 to 1.18), CAC40 (from 1.15 to 1.44), and AEX (from 0.55 to 0.34), while increased significantly in NIKKEI (from 0.05 to 7.38 ).

Table 2. Coefficients of periodical risk premia

\begin{tabular}{|c|c|c|c|c|c|c|c|c|c|}
\hline \multicolumn{2}{|c|}{ Global Stock Market Zones } & Period (1) & Period (2) & Period (3) & Period (4) & Period (5) & Period (6) & Period (7) & Period (8) \\
\hline \multicolumn{10}{|c|}{ A: American Markets } \\
\hline S\&P 500 & USA & $0.4056^{* * *}$ & 0.6342 & $1.0550 * * *$ & $0.5947 * *$ & 0.8500 & -0.0275 & $2.9708 * * *$ & 0.5552 \\
\hline NASDAQ IXIC & USA & 1.9091 & 1.9779 & 4.3933 & 8.1503 & $34.3557 * * *$ & 1.8248 & $21.1663 * *$ & -0.9510 \\
\hline DJIA & USA & 5.7077 & 10.1062 & 6.1009 & $15.0289^{*}$ & $50.3427 * * *$ & 0.7219 & $19.4384 * * *$ & 3.2212 \\
\hline IPC & Mexico & 0.2036 & $0.2726^{* * *}$ & 0.0537 & -1.0098 & 0.2107 & 10.7903 & $0.6648 * * *$ & -0.2731 \\
\hline IBOVESPA & Brazil & $6.0351 * * *$ & $1.1761 * * *$ & 0.0007 & 0.0863 & -16.3813 & 3.1549 & $9.4916^{* * *}$ & -0.2782 \\
\hline MERVAL & Argentina & & 0.0088 & $0.0230 * * *$ & $-0.0823^{*}$ & -1.3439 & 0.2387 & $0.1187 * * *$ & -0.0196 \\
\hline \multicolumn{10}{|c|}{ B: Asian and Australian Markets } \\
\hline ASX (AORD) & Australia & $0.0973^{* * *}$ & 0.0882 & $1.6852 * * *$ & -0.0096 & $3.3225^{* * *}$ & -0.0150 & 0.2271 & $0.6948^{*}$ \\
\hline HANG SENG & Hong Kong & $1.6558^{* * *}$ & 0.0225 & 0.0341 & $0.0831 * * *$ & 4.6248 & 0.0087 & $1.5423 * * *$ & 0.1939 \\
\hline NIKKEI 255 & Japan & $0.0541 * *$ & $7.3777 * * *$ & $0.2934 * * *$ & -0.0188 & 0.9454 & -0.1440 & 0.2889 & -6.0669 \\
\hline STRAITS & Singapore & $0.0887 * *$ & -0.0019 & 0.0099 & $0.3136^{* *}$ & 0.8036 & 0.8150 & $13.0314 * * *$ & -0.2470 \\
\hline FTSE Malaysia & Malaysia & -0.0019 & 0.0135 & -0.0003 & 0.0026 & $1.2581^{*}$ & -11.1931 & $20.9459 * * *$ & 0.3194 \\
\hline BSE & India & & -0.0146 & 0.0230 & $0.2788^{* * *}$ & 0.0186 & -0.1915 & $0.7550 * * *$ & 0.7416 \\
\hline JKSE & Indonesia & & 0.0036 & $-0.0496^{* * *}$ & $0.1384 * * *$ & $0.4712 * *$ & -0.0008 & 0.2013 & $5.4379 *$ \\
\hline KOPS & South Korea & & -0.0079 & 0.0011 & $0.2272 * * *$ & 1.0378 & 1.1791 & $1.3837 * * *$ & $4.5972 *$ \\
\hline TA 100 & Iran & & 0.0052 & 0.0643 & -0.0005 & $1.2349^{*}$ & 0.8598 & 0.2177 & $0.2008^{* *}$ \\
\hline TSEC & Taiwan & & $0.3163^{* *}$ & $0.0624 * *$ & -0.0632 & 0.3720 & 0.8457 & $666.49 * * *$ & -26.0194 \\
\hline SHANGHAI & China & & & $7.4672 *$ & $0.0421 * *$ & $-3.9968 * * *$ & $11.1724^{*}$ & $11.95 * * *$ & -0.1907 \\
\hline NZX 50 & New Zealand & & & & 0.9230 & $4.3204 * *$ & $-0.1646^{* * *}$ & $0.2431 * *$ & $0.8815^{*}$ \\
\hline \multicolumn{10}{|c|}{ C: European Markets } \\
\hline FTSE 100 & UK & -0.0321 & $4.1497 * * *$ & 0.0121 & $1.3843 * * *$ & $5.6670 * * *$ & $9.4660^{*}$ & $1.0829 * * *$ & 1.5227 \\
\hline CAC 40 & France & $1.1470 * * *$ & $1.4364 * * *$ & 0.1755 & $1.0579 * * *$ & $3.1878 * * *$ & -0.0067 & $0.9569 * * *$ & $0.4833 * *$ \\
\hline DAX & German & $0.4790 * * *$ & 0.1683 & $0.0639 *$ & $0.2832 * * *$ & 0.1929 & -0.0102 & 0.0914 & 0.0186 \\
\hline SSMI SWISS & Switzerland & -0.0080 & $0.6810^{* * *}$ & -0.0065 & $0.3491 * * *$ & 0.1999 & 0.1707 & 0.2199 & 0.0334 \\
\hline AEX & Netherlands & $0.5450 * * *$ & 0.3391 & $0.5343 * * *$ & $0.3029 *$ & 0.0026 & -0.0282 & $1.4157 * * *$ & $0.4153 * * *$ \\
\hline ATX & Austria & 0.0135 & $0.4670^{* * *}$ & $0.2093^{* *}$ & $-20.4483 * * *$ & 0.0112 & -0.1861 & 0.1096 & $-0.2406 * *$ \\
\hline ATHENS & Greece & & & 0.4460 & $0.3708 * * *$ & 0.0647 & $-2.9418 * *$ & 0.0092 & $-39.3511 *$ \\
\hline OMXS & Sweden & & & $-0.2005^{* * *}$ & $0.3217 * * *$ & 0.1643 & 1.8725 & 4.8160 & $0.5040^{* *}$ \\
\hline OSLO & Norway & & & -0.4327 & $-21.4914 * * *$ & $4.0986^{* * *}$ & 0.0035 & $1.9758 * * *$ & -0.0474 \\
\hline IGBM Madrid & Spain & & & -0.0857 & 0.0325 & $1.3824^{*}$ & 0.0403 & 0.0204 & $0.3470^{*}$ \\
\hline EURONEX BEL20 & Belgium & & & & $0.4891 * *$ & 0.0250 & $0.0851 * *$ & $0.6572 *$ & -0.0983 \\
\hline
\end{tabular}

Notes:***,**, ${ }^{*}$ Statistically significant at $1 \%, 5 \%$ and $10 \%$ level, respectively. Detailed information with z-statistics is not presented here due to its bulkiness, but it can be produced upon request. 
During the recovery period (post Asian crisis, 1999 - 2002), there is no evidence of risk premia in American stocks (except S\&P500 and MERVAL). Asian and Australian stocks also show different response during the same period, in which risk premia is only evident in ASX (AORD), NIKKEI255, TSEC and SHANGHAI. In JKSE, the negative sign suggests investors bore the entire risk during the period. Later on, evidence of risk premia is found during the economic boom (2003 - 2007) for the S\&P500 and DJIA (for American markets), HANG SENG, STRAITS, BSE, JKSE, KOPS and SHANGHAI (for Asian and Australian markets), and most of European markets (except ATX, OSLO and IGBM).

A very high risk premia is evident before the global financial crisis $(2007$ - 2008) in American Markets: NASDAQ IXIC (34.36) and DJIA (50.36). Other markets also suggest a relatively high risk premia, such as ASX AORD (3.32), AZX50 (4.32), FTSE100 (5.67), CAC40 (3.19), and OSLO (4.10). But, the global financial crisis (2008 - 2009) appears to have adverse effects on risk premia for almost all stock returns globally. The exceptions are SHANGHAI, FTSE100 and EURONEX BEL20, in which the risk premia seems to have increased as follows: SHANGHAI (from -3.99 to 11.17), FTSE (from 5.67 to 9.47), and EURONEX BEL20 (from 0.03 to 0.09 ). The post crisis recovery (2009-2010) seems to have reversed the adverse response of the crisis period, by creating risk premia in all the American markets and most of the Asian and Australian markets except ASX (AORD), NIKKEI255, JKSE, and TA100. In Europe, out of eleven markets, risk premia is only evident in five of them (FTSE100, CAC40, AEX, OSLO, and EURONEX BEL20).

The period covering the Greece crisis appears to have eliminated the risk premia in all the American markets and most of the Asian, Australian, and European markets. Asian and Australian markets that seem to carry a risk premia during this period are ASX (AORD), JKSE, KOPS, TAN100, and NZX50, whereas the only European markets are CAC40, AEX, and OMXS.

Figure 3 plots the alley of the risk premia coefficients in global stock returns during the eight sample periods. This alley is cyclical, corresponding to economic cycles, suggesting a direct relationship between global economic conditions and markets' adjustments for risk. American markets seem to follow an identical alley, with the exception on IBOVESPA before the global financial crisis (period 5), and IPC during the global crisis (period 6). In USA, the DJIA and NASDAQ IXIC are highly identical. The identical cycles are also evident in the Asian and Australian markets with the exception of SHANGHAI (pre and during the global financial crisis) and FTSE Malaysia (during the global financial crisis). Likewise, European markets exhibit the same pattern except OSLO and ATX (during the economic boom) and ATHENS (from the global financial crisis to its current debt crisis). The most adverse effect of the Greece crisis on risk premia can be observed in STRAITS and ATHENS itself. Overall, despite differences in the risk compensation content, favorable economic conditions appear to correspond to improved risk premia in most markets. This suggests that investors significantly bear the risk during bad times as stock prices fail to provide the required risk compensation. One explanation may be that, during bad times, market agents tend to allocate more financial resources in recovery endeavors, and that they are prepared to share the recovery costs. Their decisions to bear the recovery costs can be related to the rational expectation hypothesis in efficient markets, as they expect to benefits during good economic times. 
American

Markets

Asian and

Australian

Markets

European

Markets

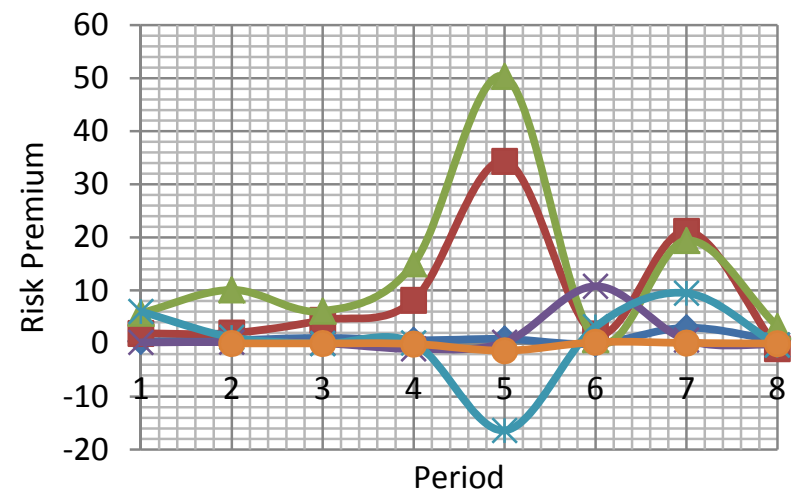

$\longrightarrow$ S\&P 500 USA

$\simeq$ NASDAQ IXIC USA

$\longrightarrow$ DJA USA

$\simeq$ IPC Mexico

$\because$ IBOVESPA Brazil

$\longrightarrow$ MERVAL Argentina

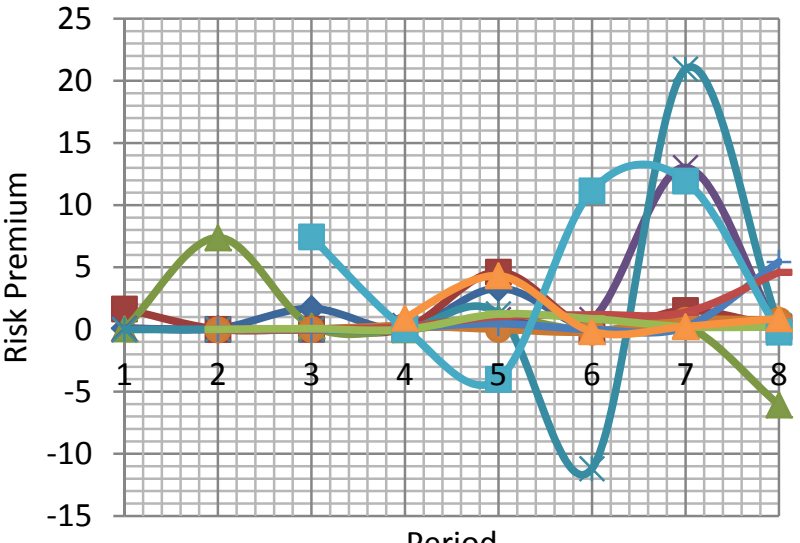

Period

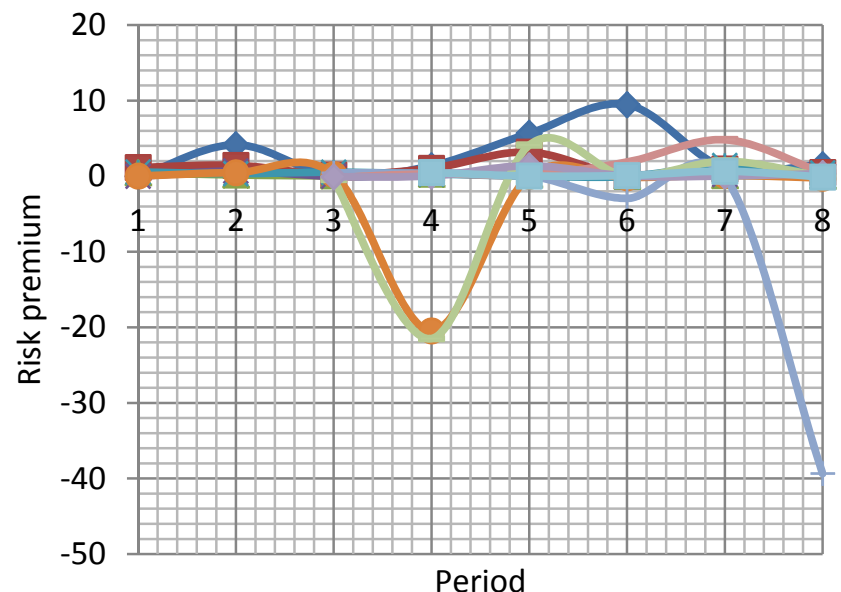

Figure 3 . The alley of periodical risk premia
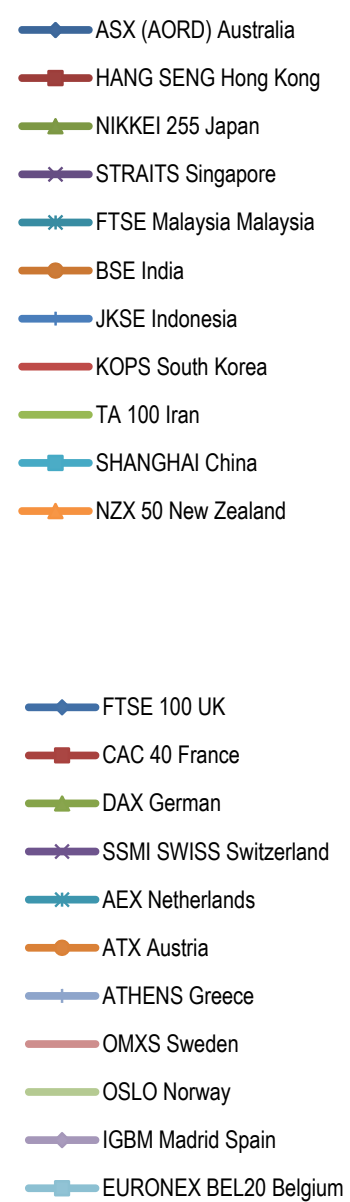
Table 3. Coefficients of periodical information asymmetry

\begin{tabular}{|c|c|c|c|c|c|c|c|c|c|}
\hline \multicolumn{2}{|c|}{ Global Stock Market Zones } & Period (1) & Period (2) & Period (3) & Period (4) & Period (5) & Period (6) & Period (7) & Period (8) \\
\hline \multicolumn{10}{|c|}{ A: American Markets } \\
\hline S\&P 500 & USA & $0.3819^{* * *}$ & 0.0747 & $-0.3379 * * *$ & $0.4449 * * *$ & $-0.4995 * * *$ & $-0.3175^{*}$ & $0.1057 * * *$ & 0.0251 \\
\hline NASDAQ IXIC & USA & $-0.0850 * * *$ & $-0.1396 * * *$ & $-0.1084 * * *$ & $-0.0339 * * *$ & $-0.2437 * * *$ & $-0.2199 * * *$ & $-0.1778 * * *$ & $-0.1724 * * *$ \\
\hline DJIA & USA & $-0.0601 * * *$ & $-0.2137 * * *$ & $-0.1183 * * *$ & $-0.0843 * * *$ & $-0.2361 * * *$ & $-0.1633 * * *$ & $-0.0881 * *$ & $-0.2007 * * *$ \\
\hline IPC & Mexico & $0.1740 * * *$ & $-0.0786^{* * *}$ & $0.0087 * * *$ & $0.4269^{* * *}$ & -0.5578 & 0.0030 & $0.3120^{* * *}$ & 0.1588 \\
\hline IBOVESPA & Brazil & $0.0478 * * *$ & $-0.0622 * * *$ & $-0.1874 * *$ & $0.5103^{* * *}$ & -0.0181 & $-0.0150 * * *$ & 0.0907 & -0.1688 \\
\hline MERVAL & Argentina & & -1.1459 & $-0.3697 * * *$ & $0.3914 * * *$ & $-0.9790 * * *$ & -0.1001 & $0.6650 * * *$ & 0.0288 \\
\hline \multicolumn{10}{|c|}{ B: Asian and Australian Markets } \\
\hline ASX (AORD) & Australia & 0.0644 & 0.0530 & $-0.3640 * * *$ & $0.5156^{* * *}$ & $-0.7986 * * *$ & -0.2045 & $0.3177 * * *$ & $-0.2633 * *$ \\
\hline HANG SENG & Hong Kong & $0.1735^{* * *}$ & -0.0826 & $-0.1104 *$ & $0.6319^{* * *}$ & -0.0934 & -0.1786 & $0.2315^{* * *}$ & $-0.3939 * * *$ \\
\hline NIKKEI 255 & Japan & $-0.2929 * * *$ & $-0.2852 * * *$ & $-0.2621 * * *$ & $0.3212 * * *$ & $-0.4369^{* *}$ & $-0.6714 * * *$ & -0.1151 & $0.1346^{* * *}$ \\
\hline STRAITS & Singapore & $-0.1609 * * *$ & -0.0659 & $-0.2048 * * *$ & $0.5227^{* * *}$ & $-0.3727 * * *$ & $-0.2925 * * *$ & -0.0799 & 0.0142 \\
\hline FTSE Malaysia & Malaysia & $-0.2495 * * *$ & $-0.4725 * * *$ & $-0.3036 * * *$ & $0.4594 * * *$ & $-0.9295 * * *$ & -0.0458 & $0.0955^{* * *}$ & $0.2268 * *$ \\
\hline BSE & India & & -0.1753 & $-0.1408^{*}$ & $0.6868^{* * *}$ & -0.0061 & -0.0406 & $0.3365^{* * *}$ & 0.0462 \\
\hline JKSE & Indon & & -0.28 & & $0.7089 * * *$ & -0.3 & -0.2 & 0.59 & $0.1463 * *$ \\
\hline KOPS & Korea & & 0.0270 & $-0.2672 * * *$ & $0.4481 * * *$ & $-0.8867 * * *$ & $-0.3191 * * *$ & 0.25 & 0.0756 \\
\hline TA 100 & Iran & & 0.1717 & -0.0339 & 3.0333 & & -0.1594 & 0.5560 & $-0.4534 * * *$ \\
\hline TSEC & Taiwan & & $-0.3320 * * *$ & $-0.4671 * * *$ & $0.2104 * * *$ & $-0.4235^{* *}$ & $-0.2521 * * *$ & $0.0043 * * *$ & -0.0000 \\
\hline SHANGHAI & China & & & $-0.0708 * *$ & 0.1116 & $0.0407 * * *$ & -0.0246 & $0.0316^{* *}$ & $-0.3140 * * *$ \\
\hline NZX 50 & New Zealand & & & & $0.1263 * *$ & $-0.2884 * * *$ & -0.0886 & $0.5366^{* * *}$ & -0.0250 \\
\hline \multicolumn{10}{|c|}{ C: European Markets } \\
\hline FTSE 100 & UK & $0.2476^{* * *}$ & -0.0437 & $-0.3750 * * *$ & $0.3651 * * *$ & $-0.3730 * * *$ & $-0.1868 * * *$ & 0.192 & 0.0204 \\
\hline CAC 40 & France & $-0.1688 * * *$ & $0.1927 * * *$ & $-0.2716 * * *$ & $0.3252 * * *$ & $-0.4150 * * *$ & -0.7384 & $0.1710^{* *}$ & $-0.2648 * * *$ \\
\hline DAX & German & $0.3020 * * *$ & 0.9706 & $-0.4226 * * *$ & $0.5208^{* * *}$ & -0.2528 & -0.6380 & 0.5792 & -0.0323 \\
\hline SSMI SWISS & Switzerland & $0.4045^{* * *}$ & $0.1241 * * *$ & $-0.3683 * * *$ & $0.5091 * * *$ & -0.3559 & -0.0936 & 0.5520 & -1.1479 \\
\hline AEX & Netherlands & $0.6116^{* * *}$ & 0.2350 & $-0.4051 * * *$ & $0.2880^{* * *}$ & $-0.4949 * *$ & $-0.4417 * *$ & $0.1075 * * *$ & $-0.4181 * * *$ \\
\hline ATX & Austria & $0.3226^{* * *}$ & $-0.3724 * * *$ & $-0.1402 *$ & $0.2328^{* * *}$ & $-0.4713^{* *}$ & $-0.5327 * * *$ & 0.4266 & $-0.4153 * * *$ \\
\hline ATHENS & Greece & & & $-0.2845^{* * *}$ & $0.4759 * * *$ & $-0.3789 * *$ & $-0.1528 * * *$ & -0.7198 & $-0.0573 *$ \\
\hline OMXS & Sweden & & & $-0.5822 * * *$ & $0.3880^{* * *}$ & -1.0471 & -0.0310 & -0.0120 & $-0.2213 * * *$ \\
\hline OSLO & Norway & & & $-0.4569 * * *$ & $0.1738 * * *$ & $-0.9461 * * *$ & -0.8564 & $0.2529 * * *$ & -0.1472 \\
\hline IGBM Madrid & Spain & & & $-0.6420 * * *$ & $0.5112 * * *$ & $-0.3581 * * *$ & $-0.2453^{*}$ & 0.0377 & $-0.3049 * * *$ \\
\hline EURONEX BEL20 & Belgium & & & & $0.1933 * *$ & -1.8504 & $0.6306 * * *$ & -0.2209 & $-0.5277 * * *$ \\
\hline
\end{tabular}

Notes: $* * * * *, *$ Statistically significant at $1 \%, 5 \%$ and $10 \%$ level, respectively. Detailed information with z-statistics is not presented here due to its bulkiness, but it can be produced in request.

\subsubsection{Information Asymmetry}

Table 3 reports the coefficients for information asymmetry $\left(\pi_{2}\right)$ on stock return volatility, corresponding to the variance equation (2). Most of the estimated coefficients are statistically significant at 1 percent level.

Before the Asian crisis (1990 - 1997), markets appear to have reacted differently to news. For USA markets, bad news appears to have induced more volatility than good news in the DJIA (-0.06) and NASDAQ IXIC (-0.09), while the S\&P500 (0.38) is contrary. South American markets reacted similar to the S\&P500: with IPC (0.17) and IBOVESPA (0.05). Asian and Australian markets provide evidence of the leverage effect in NIKKEI255 $(-0.29)$, STRATS (-0.16), and FTSE Malaysia $(-0.25)$, but not in ASX (0.06) and HANG SENG (0.17). In Europe, only the CAC40 (-0.17) seem to have a leverage effect during this period.

Some differences also appear during the Asian crisis (1997 - 1999), with leverage effects in American markets, except the S\&P500 (0.07). Also, Asian and Australian markets show the leverage effects except for ASX (0.05), KOPS (0.03), and TA100 (0.17). For European markets, the leverage effect can be found in the FTSE100 (-0.04) and $\operatorname{ATX}(-0.37)$.

During the recovery of the Asian crisis (1999 - 2002), information asymmetry is evident in all markets globally, except the IPC (0.01). Interestingly, the reverse appears to have occurred during the economic boom (2003 2007), in which the leverage effects disappeared in most markets, except in NASDAQ IXIC and DJIA (with -0.03 and -0.08 , respectively). Thereafter, leverage effects were restored in all global markets before the global financial crisis $(2007-2008)$, and were maintained during the crisis $(2008-2009)$ except for the IPC and EURONEX BEL20. 
American

Markets
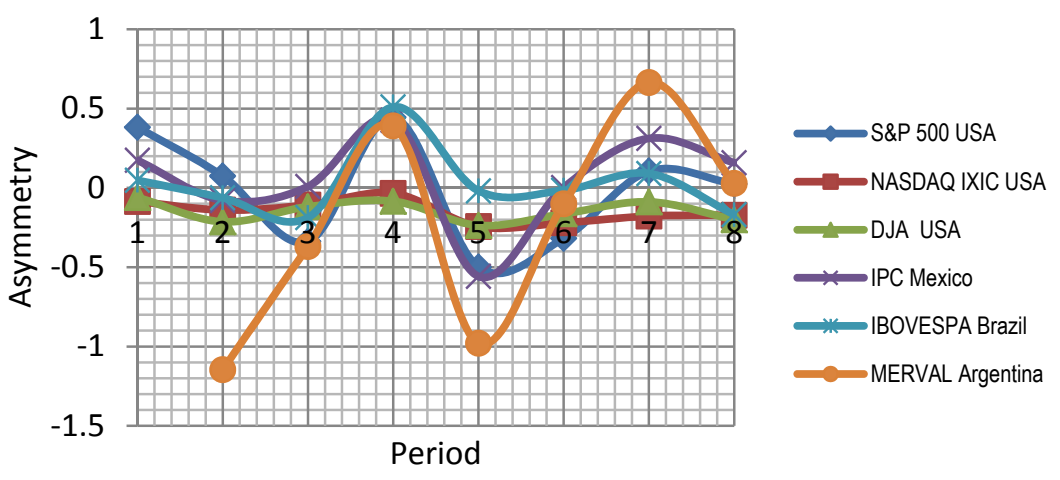

Asian and

Australian

Markets
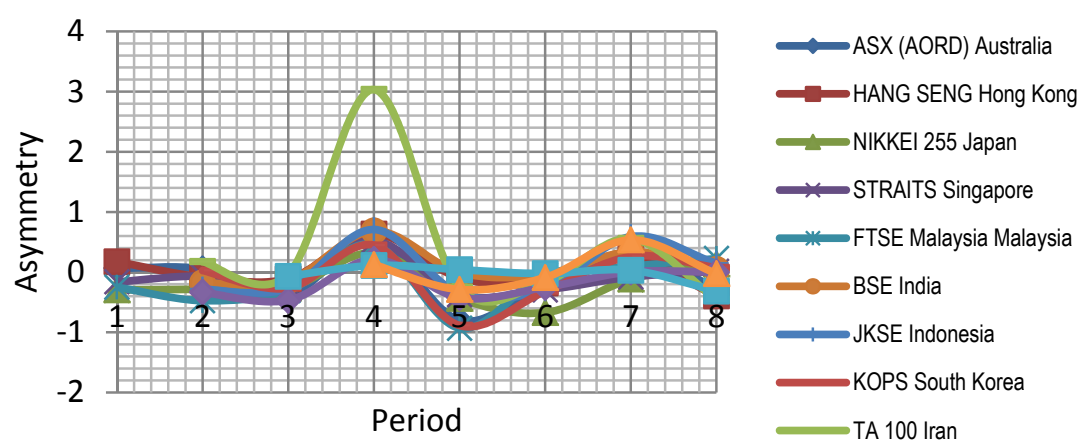

Europea
Markets
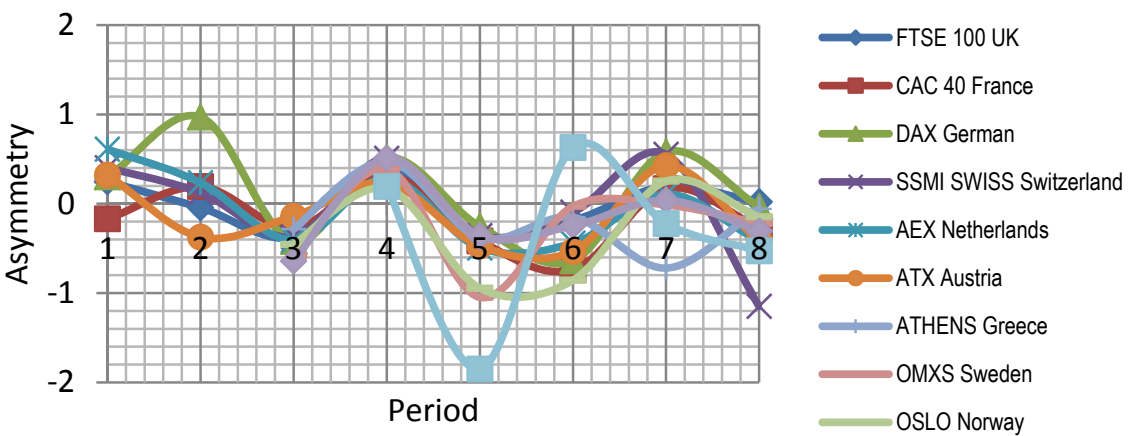

Figure 4. The alley of periodical information asymmetry in stock returns

The post crisis recovery $(2009$ - 2010) shows mixed asymmetric response globally. Overall, the leverage effects that existed between 2007 and early 2009 seem to have disappeared in many markets. The only exceptions are NASDAQ IXIC and DJIA (with -0.18 and -0.09 , respectively), which are consistent with the response during the economic boom (2003 - 2007), NIKKEI255 (-0.12), STRAITS (-0.08), ATHENS (-0.72), OMXS (-0.01), and EURONEX BEL20 (-0.22).

During the Greece crisis $(2010$ - 2011), American markets seem to have had maintained the same position as the post crisis recovery period, except IBOVESPA. Asian and Australian markets show some changes, except FTSE Malaysia, BSE, JKSE, and KOPS. Further, all European markets show leverage effects, except the FTSE100.

Figure 4 plots an alley of the estimated asymmetry coefficients. They provide strong evidence that leverage effects in global stock returns are cyclically responsive to economic cycles. Moreover, despite different degrees of responsiveness, they show a tendency of co-movement along the cycles, in which leverage effects tend to be lower during good economic conditions. This means, bad news tend to increase volatility more than good news during bad economic conditions like the Asian Crisis (2007 - 1999), pre and during the global crisis (2007 2009), and the Greece crisis (2010 - 2011). This may suggest that, market agents tend to be more sensitive to bad news during bad times than during good times. Hence, this high sensitivity is likely to trigger more chaos in the market, in its course of the adjustment, leading to more volatility. On the other hand, market agents appear to be more confident during good times. Their reaction to bad news becomes routine, thereby creating calmness in the 
adjustment process.

For American markets, the Brazilian market (IBOVESPA) appears to be the most sensitive to global economic cycles, whereas the USA markets (NASDAQ IXIC and DJIA) are less sensitive. Of all the global markets, these two USA markets are the only that have maintained leverage effects throughout the time since 1990, differing from the S\&P500. Asymmetry effects in Asian and Australian markets are highly identical, except the TA100, which appear to have the lowest leverage effects during the economic boom $(2003$ - 2007). European markets also show identical patterns. However, it is worth to observe that the Greece crisis seems to be associated with more leverage effects in European markets than the rest of the world.

\subsubsection{Volatility Persistence}

Table 4 presents the estimated coefficients $(\beta)$ for volatility persistence corresponding to the variance equation (2). Almost all of them are statistically significant at 1 percent level. Overall volatility persistence differs across stock markets, with the most highly persistent stock returns found in the two USA markets (NASDAQ IXIC and DJIA). The cyclical alleys of the persistence are clearly depicted in Figure 5. The general observation is that American markets follow an identical persistence pattern, with exceptional swings in the Mexican market (IPC) during and after the economic boom (2003 - 2008). In these American markets, the Asian crisis (2007 - 2009) seems to have negligible effect on volatility persistence. But, an increase is notable after the crisis towards the economic boom (1999-2007), followed by a substantial decrease before the global crisis (2007-2008). This was then followed by an increase during the crisis (2008-2009) towards the crisis recovery (2009-2010). Like the Asian crisis, the Greece crisis appears to have no significant impact on volatility persistence in American markets, except in Argentina (MERVAL) where persistence decreases from 0.76 to 0.50 .

Table 4. Periodical volatility persistence

\begin{tabular}{|c|c|c|c|c|c|c|c|c|c|}
\hline \multicolumn{2}{|c|}{ Global Stock Market Zones } & Period (1) & Period (2) & Period (3) & Period (4) & Period (5) & Period (6) & Period (7) & Period (8) \\
\hline \multicolumn{10}{|c|}{ A: American Markets } \\
\hline S\&P 500 & USA & $0.6232 * * *$ & $0.6263 * * *$ & $0.6970^{* * *}$ & $0.6704 * * *$ & $0.4854 * * *$ & $0.5863 * * *$ & $0.7525 * * *$ & $0.6726^{* * *}$ \\
\hline NASDAQ IXIC & USA & $0.9160 * * *$ & $0.8918^{* * *}$ & $0.9404 * * *$ & $0.9920 * * *$ & $0.6987 * * *$ & $0.9657 * * *$ & $0.9130 * * *$ & $0.9697 * * *$ \\
\hline DJIA & USA & $0.9637 * * *$ & $0.8787 * * *$ & $0.9655^{* * *}$ & $0.9716^{* * *}$ & $0.8355^{* * *}$ & $0.9742 * * *$ & $0.9814 * * *$ & $0.9690 * * *$ \\
\hline IPC & Mexico & $0.5686^{* * *}$ & $0.6103 * * *$ & $0.6937 * * *$ & $0.4269 * * *$ & $0.6902 * * *$ & $0.5351 * * *$ & $0.7515 * * *$ & $0.7034 * * *$ \\
\hline IBOVESPA & Brazil & $0.1983 * * *$ & $0.5457 * * *$ & $0.5925 * * *$ & $0.6431 * * *$ & $0.1691 * * *$ & $0.5128 * * *$ & $0.6039 * * *$ & $0.7479 * * *$ \\
\hline MERVAL & Argentina & & $0.6201 * * *$ & $0.7049 * * *$ & $0.6424 * * *$ & $0.6569^{* * *}$ & $0.6323 * * *$ & $0.7617 * * *$ & $0.5004 * * *$ \\
\hline \multicolumn{10}{|c|}{ B: Asian and Australian Markets } \\
\hline ASX (AORD) & Australia & $0.6463 * * *$ & $0.7102 * * *$ & $0.6698 * * *$ & $0.6452 * * *$ & $0.7217 * * *$ & $0.5265 * * *$ & $0.7611 * * *$ & $0.7168 * * *$ \\
\hline HANG SENG & Hong Kong & $0.4458 * * *$ & $0.5612 * * *$ & $0.5999^{* * *}$ & $0.6996^{* * *}$ & $0.2539^{* * *}$ & $0.5892 * * *$ & $0.7019 * * *$ & $0.6855^{* * *}$ \\
\hline NIKKEI 255 & Japan & $0.6846^{* * *}$ & $0.4109^{* * *}$ & $0.6792 * * *$ & $0.6712 * * *$ & $0.4714^{* * *}$ & $0.5524 * * *$ & $0.6806^{* * *}$ & $0.8242 * * *$ \\
\hline STRAITS & Singapore & $0.6914 * * *$ & $0.6411^{* * *}$ & $0.6210^{* * *}$ & $0.7573 * * *$ & $0.4799 * * *$ & $0.4778 * * *$ & $0.6607 * * *$ & $0.5839 * * *$ \\
\hline FTSE Malaysia & Malaysia & $0.6078 * * *$ & $0.6996^{* * *}$ & $0.7091 * * *$ & $0.6283 * * *$ & $0.7108^{* * *}$ & $0.4142 * * *$ & $0.1710^{* * *}$ & $0.5275 * * *$ \\
\hline BSE & India & & $0.6034 * * *$ & $0.6822 * * *$ & $0.5987^{* * *}$ & $0.5055^{* * *}$ & $0.5075 * * *$ & $0.6617 * * *$ & $0.6120^{* * *}$ \\
\hline JKSE & Indonesia & & $0.6858 * * *$ & $0.6920 * * *$ & $0.6652 * * *$ & $0.6853^{* * *}$ & $0.4174 * *$ & $0.8078 * * *$ & $0.4981 * * *$ \\
\hline KOPS & South Korea & & $0.4528 * * *$ & $0.6842 * * *$ & $0.6858 * * *$ & $0.8093 * * *$ & $0.4940 * * *$ & $0.7656^{* * *}$ & $0.6690 * * *$ \\
\hline TA 100 & Iran & & $0.3685 * * *$ & $0.4040 * * *$ & $0.6376^{* * *}$ & $0.5638^{* * *}$ & $0.3528^{*}$ & $0.8140 * * *$ & $0.7283 * * *$ \\
\hline TSEC & Taiwan & & $0.7041^{* * *}$ & $0.6743^{* * *}$ & $0.7466^{* * *}$ & $0.6354 * * *$ & $0.5024 * * *$ & $0.0815^{* * *}$ & 0.0546 \\
\hline SHANGH & China & & & $0.4058 * * *$ & $0.6896^{* * *}$ & $0.3952 * * *$ & 0.0108 & 0.1009 & $0.7119 * * *$ \\
\hline NZX 50 & New Zealand & & & & $0.5431 * * *$ & $0.5715 * * *$ & $0.6434 * * *$ & $0.7741 * * *$ & $0.7496 * * *$ \\
\hline \multicolumn{10}{|c|}{ C: European Markets } \\
\hline FTSE 100 & UK & $0.6768 * * *$ & $0.5488 * * *$ & $0.7152^{* * *}$ & $0.6780^{* * *}$ & $0.5588^{* * *}$ & $0.4328^{*}$ & $0.7962 * * *$ & $0.6460 * * *$ \\
\hline CAC 40 & France & $0.6508^{* * *}$ & $0.5680^{* * *}$ & $0.6116^{* * *}$ & $0.7056^{* * *}$ & $0.4935^{* * *}$ & $0.5680 * * *$ & $0.7982 * * *$ & $0.6839 * * *$ \\
\hline DAX & German & $0.6531 * * *$ & $0.6928 * * *$ & $0.7112 * * *$ & $0.7041 * * *$ & $0.6674 * * *$ & $0.5019 * * *$ & $0.7654 * * *$ & $0.6704 * * *$ \\
\hline SSMI SWISS & Switzerland & $0.6609 * * *$ & $0.4837 * * *$ & $0.7315 * * *$ & $0.6570 * * *$ & $0.6613^{* * *}$ & $0.5647 * * *$ & $0.8098 * * *$ & $0.6974 * * *$ \\
\hline AEX & Netherlands & $0.6769^{* * *}$ & $0.6291 * * *$ & $0.7366^{* * *}$ & $0.6939 * * *$ & $0.7030^{* * *}$ & $0.5386 * * *$ & $0.8594 * * *$ & $0.7658^{* * *}$ \\
\hline ATX & Austria & $0.6782 * * *$ & $0.6164 * * *$ & $0.6101 * * *$ & $0.6803 * * *$ & $0.6046^{* * *}$ & $0.3445 * *$ & $0.7874 * * *$ & $0.6743 * * *$ \\
\hline ATHENS & Greece & & & $0.6408 * * *$ & $0.6857 * * *$ & $0.7190 * * *$ & $0.2237 * * *$ & $0.7611 * * *$ & $0.0190 * * *$ \\
\hline OMXS & Sweden & & & $0.6587 * * *$ & $0.6460 * * *$ & $0.5798^{* * *}$ & 0.5351 & 0.4179 & $0.7235 * * *$ \\
\hline OSLO & Norway & & & $0.6488 * * *$ & $0.7100 * * *$ & $0.5615^{* * *}$ & $0.6037 * * *$ & $0.8107 * * *$ & $0.7419 * * *$ \\
\hline IGBM Madrid & Spain & & & $0.7049^{* * *}$ & $0.6575^{* * *}$ & $0.4016^{* * *}$ & 0.2861 & $0.7705^{* * *}$ & $0.6952 * * *$ \\
\hline EURONEX BEL20 & Belgium & & & & $0.6825 * * *$ & $0.6690 * * *$ & $0.6214 * * *$ & $0.8114 * * *$ & $0.7138 * * *$ \\
\hline
\end{tabular}

Notes: $* * * * *, *$ Statistically significant at $1 \%, 5 \%$ and $10 \%$ level, respectively. Detailed information with z-statistics is not presented here due to its bulkiness, but it can be produced in request. 


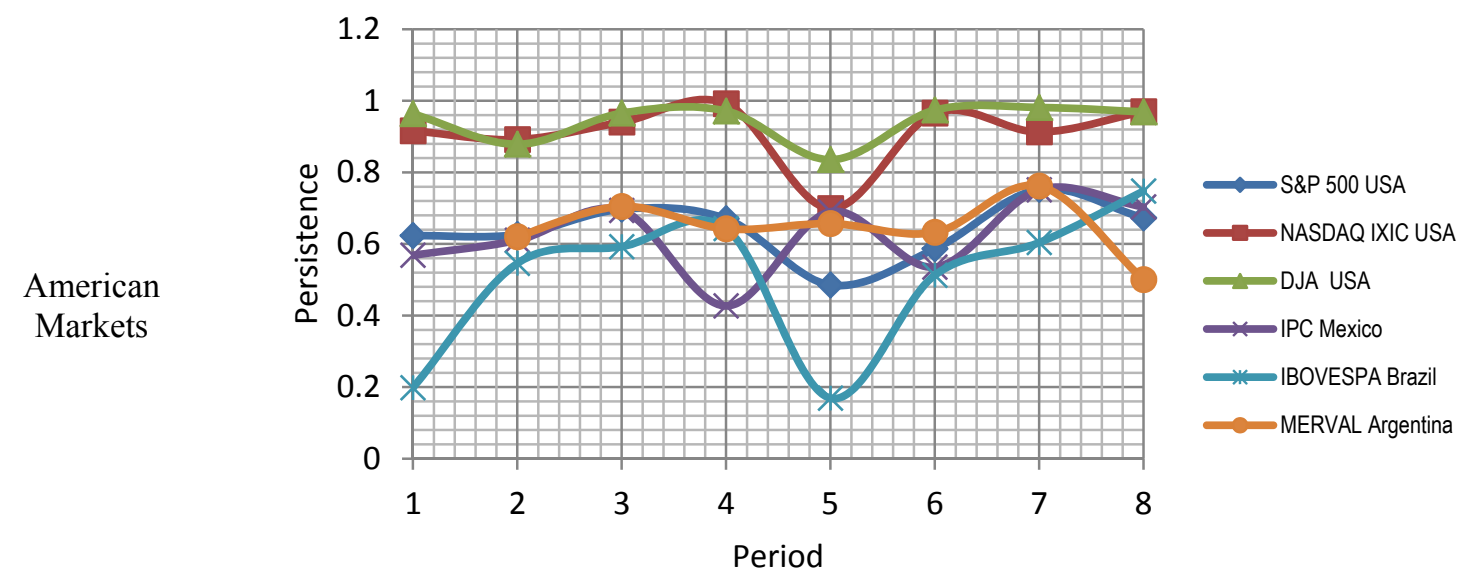

\section{Asian and Australian Markets}
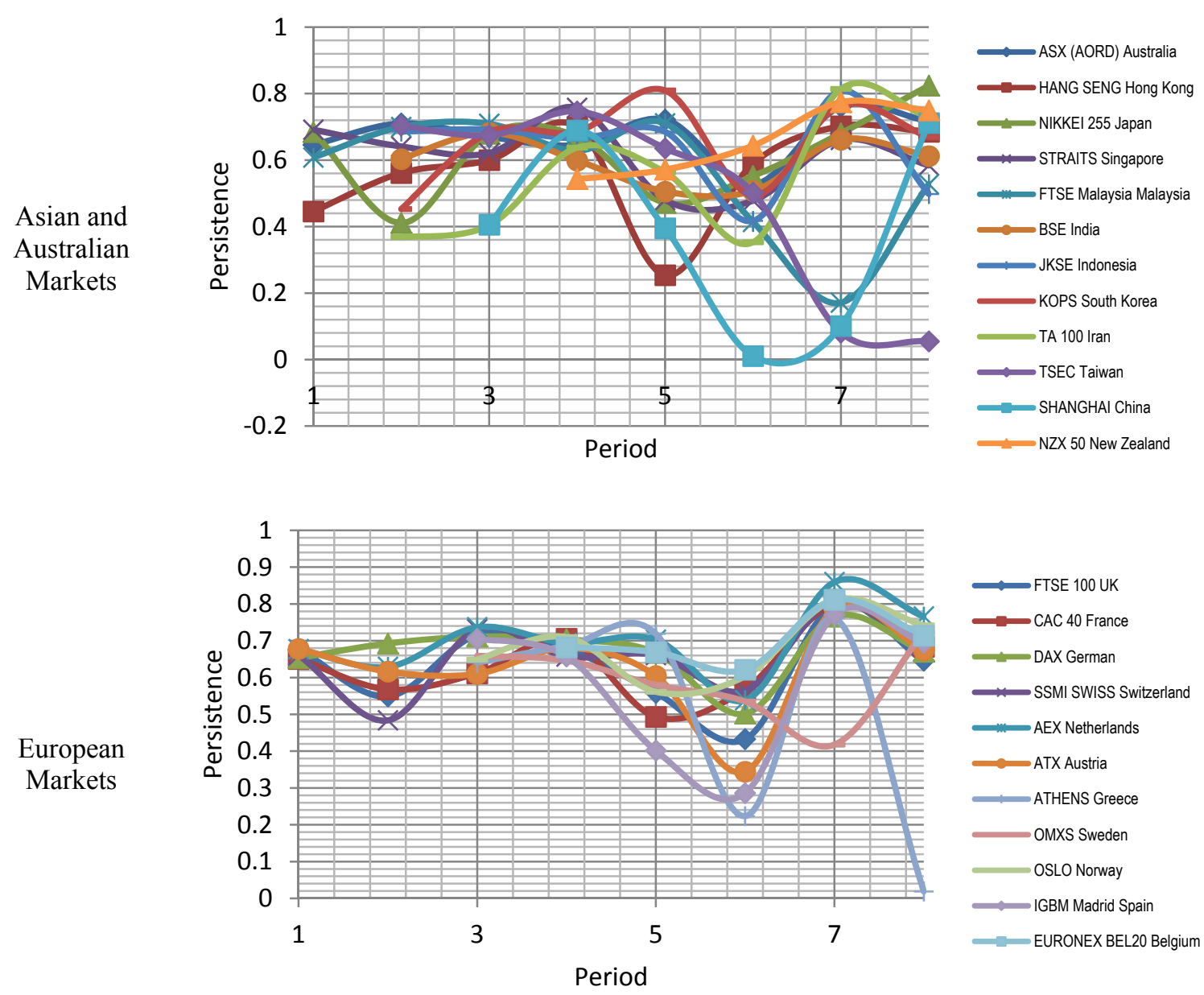

Figure 5. The alley of periodical volatility persistence

In Asian and Australian markets, the persistence in response to the Asian crisis is vivid in some stock returns, in which an increase is found in Hong Kong (HANG SENG), Australia (ASX (AORD)), and Malaysia (FTSE), while a decrease is observed in Japan (NIKKEI255) and Singapore (STRAITS). During the post crisis recovery (1999-2002), there was a slight decrease in volatility persistence for ASX (AORD), STRAITS, and TSEC, but an increase for KOPS, TA100, BSE, HANG SENG, and NIKKEI255. The economic boom (2003-2007) appears to have been associated with increase in persistence for TA100, STRAITS, HANG SENG, TSEC, and SHANGHAI, a decrease for BSE and FTSE Malaysia, but no significant changes in other markets. After the boom, a significant decrease is noticed in most of the markets (i.e. ASX (AORD), JKSE, KOPS, TA100, FTSE 
Malaysia, TSEC, and SHANGHAI) until the global crisis (2008-2009). However, the response appears to be different for NIKKEI255, HANG SENG and NZX50, where volatility persistence seems to have decreased during the crisis. The post crisis recovery (2009-2010) shows increase in volatility persistence in all stocks, followed by a decrease during the Greece crisis (2010-2011), except for SHANGHAI, NIKKEI255, and FTSE Malaysia.

For European markets, the Asian crisis (1997-1999) was aligned with decrease in volatility persistence for most of the stocks (except DAX), followed by an increase during the recovery (1999-2002) for AEX, FTSE100, SSMI SWISS, DAX, and CAC40. The economic boom (2003-2007) provided mixed responses, with persistence increase for ATX and CAC40, but a decrease for AEX, FTSE100, and SSMI SWISS. Like the Asian markets, the global crisis (2008-2009) was associated with a decrease in persistence in all the European markets, followed by an increase during the recovery (2009-2010), before decreasing again during the Greece crisis (2010-2011). The only exception is OMXS in which persistence seems to decrease consistently throughout all the periods, but seems to increase only during the Greece crisis. Overall, these cycles suggest that, mostly, volatility persistence tends to decrease during bad economic conditions, and increase during good conditions. High volatility persistence means slow adjustment process in stock markets.

\section{Concluding Remarks}

This study has employed EGARCH-M models to examine cyclical nature of stock returns in relation to economic cycles. In such, it addresses issues relating to stock return volatility, risk premium and information asymmetry. These issues have been extensively investigated in previous studies, but there exist enormous contradictions and debates. The main unclear issues relate to stock return response during bad times and good times, response to bad news and good news, and risk-return trade-off. In examining these debatable aspects, this study incorporates a wider and systematic alley of major global economic events since 1990s to the end of 2011. The main objective is to provide a corroborative evidence of the cyclicality nature of stock return volatility in the global context, and present a consolidated volatility alley in association with major economic events. Our specific results suggest different reactions amongst markets during bad and good times, and following bad and good news. However, the general view is that, with few exceptions, good economic conditions are mostly associated with a rise in stock returns and risk premia, a fall in volatility and the impact of bad news on volatility (information asymmetry), and a fall or rise in volatility persistent. It is the vice versa during bad times.

It was beyond the scope of this paper to investigate the factors for the different reactions in global stock markets. However, there are some economic and policy implications. As pointed out in Bollerslev \& Tauchen (2009), high (low) premia is a predicting sign of high (low) future returns, consistent with a common financial theory that risk premia should be highest during bad times and lowest during good times. However, this study shows that not all markets comply with this theory. Other things being equal, increase in risk premia during good times implies market adjustments to increase in volatility during the preceding bad times. That is, increase in volatility (during bad times) forces market participants to adjust the expected risk premia by increasing the demand for higher returns. Therefore, investors in these markets should not expect immediate compensation for risk during bad times since, in most markets, the highest risk premia appear to be achieved during good times. Instead, they should strategize their investment portfolio by diversifying their stocks in markets with different responses to economic shocks.

Also, the fact that not all markets are consistent with the common economic proposition of higher volatility during bad times implies differences in investors' reactions across markets, which tend to be caused by several factors like: behavioral responses relating to trading noise and the nature of information flow (French and Roll, 1986), institutional features of markets (Yen \& Lee, 2000), value of trading currency (Fang, 2002), the extent to which market are hit by economic shocks (Schwert, 1989a), and financial leverage effects (Schwert, 1989b). This is a caution to market regulators to avoid generalizing volatility measures: instead, they should apply specific measures that suit specific market circumstances. Moreover, the cyclic nature of stock return volatility emphasizes the caution by Schwertz (1989a) against regulatory motives aiming at controlling stock market volatility.

\section{Acknowledgements}

We warmly thank all those who provided valuable comments in the course of writing this paper. We are especially, grateful for various contributors during the World Finance Symposium (Shanghai, China) in December 2012, and we appreciate the journal editor and anonymous referees for their constructive feedbacks that helped to improve this paper. We accept responsibility for any remaining errors. 


\section{References}

Adrian, T., \& Rosenberg, J. (2008). Stock Return and Volatility: Pricing the Short-run and Long-run Components of Market Risk. Staff Report No. 254. New York, Federal Reserve Bank of New York.

Anderson, T. G., Bollerslev, T., Diebold, F. X., \& Ebens, H. (2001). The Distribution of Realized Stock Return $\begin{array}{lllll}\text { Volatility. Journal of } & \text { Financial }\end{array}$ http://dx.doi.org/10.1016/S0304-405X(01)00055-1

Bae, K. H., \& Karolyi, A. (1994). Good News, Bad News and International Spillovers of Stock Return Volatility Between Japan and the U.S. Pacific-Basin Finance Journal, 2(4), 405-438. http://dx.doi.org/10.1016/0927-538X(94)90003-5

Bartram, S. M., \& Wang, Y. H. (2005). Another Look at the Relationship Between Cross-market Correlation and Volatility. Finance Research Letters, 2(2), 75-88. http://dx.doi.org/10.1016/j.frl.2005.01.002

Basher, S. A., Hassan, K. M., \& Islam, A. M. (2007). Time-varying Volatility and Equity Returns in Bangladesh $\begin{array}{lllll}\text { Stock } \quad \text { Market. Applied Financial } & \text { Economics, } & 17, & \text { 1393-1407. }\end{array}$ http://dx.doi.org/10.1080/09603100600771034

Beck, T., \& Levine, R. (2004). Stock Markets, Banks, and Growth: Panel Evidence. Journal of Banking and Finance, 28(3), 423-442. http://dx.doi.org/10.1016/S0378-4266(02)00408-9

Beirne, J., Caporale, G. M., Schulze-Ghattas, M., \& Spagnolo, N. (2009). Volatility Spillovers and Contagion From Mature to Emerging Stock Markets. ECB Working Paper Series, No. 1113/November 2009. Frankfurt.

Bekaert, G., \& Harvey, C. R. (1995). Time-Varying World Market Integration. The Journal of Finance, 50(2), 403-444. http://dx.doi.org/10.1111/j.1540-6261.1995.tb04790.x

Bekaert, G., \& Wu, G. (2000). Asymmetric Volatility and Risk in Equity Markets. The Review of Financial Studies, 13(1), 1-42. http://dx.doi.org/10.1093/rfs/13.1.1

Bekaert, G., Harvey, C. R., \& Ng, A. (2005). Market Integration and Contagion. The Journal of Business, 78(1), 39-69. http://dx.doi.org/10.1086/426519

Beltratti, A., \& Morana, C. (2006). Breaks and Persistency: Macroeconomic causes of Stock Market Volatility. Journal of Econometrics, 131, 151-177. http://dx.doi.org/10.1016/j.jeconom.2005.01.007

Black, F. (1976). Studies in Stock Price Volatility Changes. The 1976 Business Meeting of the Business and Economic Statictics Section. American Statistical Association.

Bollerslev, T. (1986). Generalised Autoregressive Conditional Heteroskedasticity. Journal of Econometrics, 31(3), 307-327. http://dx.doi.org/10.1016/0304-4076(86)90063-1

Bollerslev, T., \& Tauchen, G. (2009). Expected Returns and Variance Risk Premia. Review of Financial Studies, 22(11), 4463-4492. http://dx.doi.org/10.1093/rfs/hhp008

Brandt, M. W., \& Kang, Q. (2004). On the Relationship Between the Conditional Mean and Volatility on Stock Returns: A latent VAR Approach. Journal of Financial Economics, 72, 217-257. http://dx.doi.org/10.1016/j.jfineco.2002.06.001

Campbell, J. Y. (1992). No News is Good News. Journal of Financial Economics, 31, 281-318. http://dx.doi.org/10.1016/0304-405X(92)90037-X

Campbell, J. Y., Lettau, M., Malkiel, B. G., \& Xu, Y. (2001). Have Individual Stocks Become More Volatile? An Empirical Exploration of Idiosyncratic Risk. The Journal of Finance, 57(1), 1-44. http://dx.doi.org/10.1111/0022-1082.00318

Caporale, G. M., Cipollini, A., \& Spagnolo, N. (2005). Testing for Contagion: A Conditional Correlation Analysis. Journal of Empirical Finance, 12(3), 476-489. http://dx.doi.org/10.1016/j.jempfin.2004.02.005

Caporale, G. M., Pittis, N., \& Spagnolo, N. (2006). Volatility Transmission and Financial Crises. Journal of Economics and Finance, 30(3), 376-390. http://dx.doi.org/10.1007/BF02752742

Chan, K. C., Karolyi, A., \& Stulz, R. M. (1992). Global Financial Markets and the Risk Premium on U.S. Equity. Journal of Financial Economics, 32, 137-167. http://dx.doi.org/10.1016/0304-405X(92)90016-Q

Chan, L. K. C., Hamao, Y., \& Lakonishok, J. (1991). Fundamentals and stock returns in Japan. Journal of Finance, 46(5), 1739-89. http://dx.doi.org/10.1111/j.1540-6261.1991.tb04642.x 
Choudhry, T. (1996). Stock Market Volatility and the Crash of 1987: Evidence from six Emerging Markets. Journal of International Money and Finance, 15(6), 969-981. http://dx.doi.org/10.1016/S0261-5606(96)00036-8

Corsetti, G., Pericoli, M., \& Sbracia, M. (2005). Some Contagion, Some Interdependence: More Pitfalls in Tests of Financial Contagion. Journal of International Money and Finance, 24(8), 1177-1199. http://dx.doi.org/10.1016/j.jimonfin.2005.08.012

Cunado, J., Gil-Alana, L. A., \& Perez De Gracia, F. (2005). A test for Rational Bubbles in the NASDAQ Stock Index: A Fractionally Integrated Approach. Journal of Banking and Finance, 29(10), 2633-2654. http://dx.doi.org/10.1016/j.jbankfin.2004.10.003

Donaldson, G. R., \& Kamstra, M. (1997). An Artificial Neural Network-GARCH Model for International Stock $\begin{array}{lllll}\text { Return Volatility. Journal of Empirical Finance, 4(1), 17-46. } & \text {. }\end{array}$ http://dx.doi.org/10.1016/S0927-5398(96)00011-4

Eichengreen, B. (1999). Towards a New International Financial Architecture: A Practical Post-Asia Agenda. Washington, DC, Institute for International Economics.

Engle, R. F. (1982). Autoregressive Conditional Heteroscedasticity with Estimates of the variance of U.K. Inflation. Econometrica, 50(4), 987-1008. http://dx.doi.org/10.2307/1912773

Engle, R. F., Lilien, D. M., \& Robins, R. P. (1987). Estimating Time Varying Risk Premia in the Term Structure: The ARCH-M Model. Econometrica, 55(2), 391-407. http://dx.doi.org/10.2307/1913242

Fama, E. F. (1981). Stock Returns, Real Activity, Inflation and Money. American Economic Review, 71(4), 545-565.

Fang, W. (2002). The Effect of Currency Depreciation on Stock Returns: Evidence from Five East Asian Economies. Applied Economic Letters, 9(3), 195-199. http://dx.doi.org/10.1080/13504850110054931

Forbes, K. J., \& Rigobon, R. (2002). No Contagion, Only Interdependence: Measuring Stock Market Comovements. The Journal of Finance, 57(5), 2223-2261. http://dx.doi.org/10.1111/0022-1082.00494

Frank, N., \& Hesse, H. (2009). Financial Spillovers to Emerging Markets During the Global Financial Crisis. IFM Working Paper No. WP/09/104. Washington DC.

Frank, N., Gonzales-Hermosillo, B., \& Hesse, H. (2008). Transmission of Liquidity Shocks: Evidence from the 2007 Subprime Crisis. IMF Working Paper No. WP/08/200. Washington DC.

French, K. R., \& Roll, R. (1986). Stock Return Variance: The Arrival of Information and Reaction of Traders. Journal of Financial Economics, 17(1), 5-26. http://dx.doi.org/10.1016/0304-405X(86)90004-8

French, K. R., Schwert, G. W., \& Stambaugh, R. F. (1987). Expected Stock Returns and Volatility. Journal of Financial Economics, 19, 3-29. http://dx.doi.org/10.1016/0304-405X(87)90026-2

Glosten, L. R., Jarannathan, R., \& Runkle, D. E. (1993). On the Relation between the Expected Value and the Volatility of the Nominal Excess Returns on Stocks. Journal of Finance, 48(5), 1779-1801. http://dx.doi.org/10.1111/j.1540-6261.1993.tb05128.x

Gonzales, J. G., Spencer, R. W., \& Walz, D. T. (2003). A Contemporary Analysis of Mexican Stock Market Volatility. Applied Financial Economics, 13(10), 741-745. http://dx.doi.org/10.1080/09603100210140166

Griffith-Jones, S., \& Ocampo, J. A. (2009). The Financial Crisis and its Impact on Developing Countries. Working Paper No. 53, UNDP, International Policy Centre for Inclusive Growth. Brasilia.

Hamilton, J. D., \& Lin, G. (1996). Stock Market Volatility and the Business Cycle. Journal of Applied Econometrics, $11(5)$, 573-593. http://dx.doi.org/10.1002/(SICI)1099-1255(199609)11:5<573::AID-JAE413>3.0.CO;2-T

Harvey, C. R. (1989). Forecasts of Economic Growth from the Bond and Stock Markets. Financial Analyst Journal, 45(5), 38-45. http://dx.doi.org/10.2469/faj.v45.n5.38

Jorion, P., \& Goetzmann, W. N. (1999). Global Stock Markets in the Twentieth Century. The Journal of Finance, 54(3), 953-980. http://dx.doi.org/10.1111/0022-1082.00133

Kasa, K. (1992). Common Stochastic Trends in International Stock Markets. Journal of Monetary Economics, 29(1), 95-124. http://dx.doi.org/10.1016/0304-3932(92)90025-W

King, M. A., \& Wadhwani, S. (1990). Transmission of Volatility between Stock Markets. The Review of 
Financial Studies, 3(1), 5-33. http://dx.doi.org/10.1093/rfs/3.1.5

King, M., Sentana, E., \& Wadhwani, S. (1994). Volatility and Links Between National Stock Markets. Econometrica, 62(4), 901-933. http://dx.doi.org/10.2307/2951737

Koutmos, G., Negakis, C., \& Theodossiou, P. (1993). Stochastic Behavior of the Athens Stock Exchange. Applied Financial Economics, 3(2), 119-126. http://dx.doi.org/10.1080/758532830

Lamoureux, C. G., \& Lastrapes, W. D. (1990). Heteroskedasricity in Stock Return Data: Volume versus GARCH Effects. The Journal of Finance, 45(1), 221-229. http://dx.doi.org/10.1111/j.1540-6261.1990.tb05088.x

Lintner, J. (1965). Security Prices, Risk, and Maximal Gains From Diversification. Journal of Finance, 20(4), 587-615.

Longin, F. M., \& Solnik, B. (1995). Is the Correlation in International Equity Returns Constant: 1960-1990. Journal of International Money and Finance, 14(1), 3-26. http://dx.doi.org/10.1016/0261-5606(94)00001-H

Markowitz, H. (1959) Portfolio Selection: Efficient Diversification and Investments. New York: John Wiley and Sons.

Mele, A. (2007). Asymmetric Stock Market Volatility and the Cyclical Behavior of Expected Returns. Journal of Financial Economics, 86, 446-478. http://dx.doi.org/10.1016/j.jfineco.2006.10.002

Mitton, T. (2002). A Cross-firm Analysis of the Impact of Corporate Governance on the East Asian Financial Crisis. Journal of Financial Economics, 64(2), 215-241. http://dx.doi.org/10.1016/S0304-405X(02)00076-4

Modiglian, F., \& Cohn, R. (1979). Inflation, Rational Valuation and the Market. Financial Analyst Journal, 35(2), 24-44. http://dx.doi.org/10.2469/faj.v35.n2.24

Nasseh, A., \& Strauss, J. K. (2004). Stock Prices and the Dividend Discount Model: Did their Relation Break Down in the 1990s? The Quarterly Review of Economics and Finance, 44(2), 191-207. http://dx.doi.org/10.1016/j.qref.2003.09.001

Nelson, D. B. (1991). Conditional Heteroskedasticity in Asset Returns: A New Approach. Econometica, 59, 347-370. http://dx.doi.org/10.2307/2938260

$\mathrm{Ng}$, A. (2000). Volatility Spillover Effects from Japan and the US to the Pacific-Basin. Journal of International Money and Finance, 19(2), 207-233. http://dx.doi.org/10.1016/S0261-5606(00)00006-1

Radelet, S., Sachs, J. D., Cooper, R. N., \& Bosworth, B. P. (1998). The East Asian Financial Crisis: Diagnosis, Remedies, Prospects. Brookings Papers on Economic Activities, 1, 1-90. http://dx.doi.org/10.2307/2534670

Rayhorn, C., Hassan, K. M., Yu, J. S., \& Janson, K. R. (2007). Emerging Market Efficiecies: New Zealand's Maturation Experience in the Presence of Non-Linearity, Thin Trading and Asymmetric Information. International Review of Finance, 7(2), 21-34.

Rodrik, D. (1999) The New Global Economy and Developing Countries: Making Openness Work. Washington, DC, Overseas Development Council.

Sarantis, N. (2001). Nonlinearities, Cyclical Behavior and Predictability in Stock Markets: International Evidence. International Journal of Forecasting, 17(3), 459-482. http://dx.doi.org/10.1016/S0169-2070(01)00093-0

Schwert, G. W. (1989a). Business Cycles, Financial Crises, and Stock Volatility. Carnegie-Rochester Conference Series on Public Policy, Elsevier, 31(1), 83-125.

Schwert, G. W. (1989b). Why Does Stock Market Volatility Change Over Time? Journal of Finance, 44(5), 1115-1153. http://dx.doi.org/10.1111/j.1540-6261.1989.tb02647.x

Schwert, G. W. (1990). Stock Market Volatility. Financial Analyst Journal, 46(3), 23-34. http://dx.doi.org/10.2469/faj.v46.n3.23

Schwert, G. W. (2011). Stock Volatility During the Recent Financial Crisis. NBER Working Paper Series, 16976. Cambridge.

Sharpe, W. F. (1964). Capital Asset Prices: A Theory of Market Equilibrium under Conditions of Risk. Journal of Finance, 19(3), 425-442.

Shiller, R. J. (1981). Do Stock Prices Move Too Much to be Justified by Subsequent Changes in Dividends? American Economic Review, 71(3), 421-436.

Stiglitz, J. E. (1999). Speaking at the Spring Meetings of Members of the Institute for International Finance, 
25th-26th April 1999.

Stiglitz, J. E. (2000). The Insider-What I Learnt at the World Economic Crisis. The New Republic.

Yen, Y., \& Lee, T. (2000). The Interaction and Volatility Asymmetry of Unexpected Returns in the Great China Stock Markets. Global Finance 129-149. http://dx.doi.org/10.1016/S1044-0283(00)00014-4

Appendix A. Selected global stock indices and periodical samples

\begin{tabular}{|c|c|c|c|c|c|c|c|c|c|c|}
\hline \multirow[t]{2}{*}{ Index } & \multirow[t]{2}{*}{ Country } & \multicolumn{6}{|c|}{ Sub-samples and Number of Observations } & \multirow[b]{2}{*}{$\begin{array}{l}\text { Period } \\
(6)\end{array}$} & \multirow[b]{2}{*}{$\begin{array}{l}\text { Period } \\
(7)\end{array}$} & \multirow[b]{2}{*}{$\begin{array}{l}\text { Period } \\
(8) \\
\end{array}$} \\
\hline & & Whole & $\begin{array}{l}\text { Period } \\
\text { (1) }\end{array}$ & $\begin{array}{l}\text { Period } \\
\text { (2) }\end{array}$ & $\begin{array}{l}\text { Period } \\
\text { (3) }\end{array}$ & $\begin{array}{l}\text { Period } \\
\text { (4) }\end{array}$ & $\begin{array}{l}\text { Period } \\
\text { (5) }\end{array}$ & & & \\
\hline S\&P 500 & USA & 5537 & 1896 & 438 & 945 & 1150 & 159 & 263 & 272 & 413 \\
\hline NASDAQ IXIC & USA & 5537 & 1897 & 439 & 943 & 1152 & 157 & 262 & 273 & 413 \\
\hline DJIA & USA & 5537 & 1897 & 439 & 943 & 1152 & 157 & 263 & 273 & 412 \\
\hline ASX (AORD) & Australia & 5565 & 1898 & 440 & 1010 & 1163 & 159 & 266 & 272 & 414 \\
\hline HANG SENG & Hong Kong & 5462 & 1861 & 426 & 929 & 1140 & 158 & 260 & 273 & 414 \\
\hline NIKKEI 255 & Japan & 5599 & 1851 & 426 & 925 & 1127 & 151 & 256 & 261 & 401 \\
\hline STRAITS & Singapore & 5504 & 1866 & 431 & 947 & 1154 & 151 & 259 & 275 & 420 \\
\hline FTSE 100 & UK & 5549 & 1897 & 438 & 948 & 1158 & 159 & 264 & 271 & 413 \\
\hline CAC 40 & France & 5516 & 1831 & 431 & 956 & 1174 & 159 & 266 & 276 & 422 \\
\hline DAX & German & 5328 & 1644 & 435 & 952 & 1169 & 157 & 266 & 275 & 423 \\
\hline SSMI SWISS & Switzerland & 5323 & 1660 & 438 & 945 & 1154 & 155 & 265 & 277 & 420 \\
\hline IPC & Mexico & 5016 & 1389 & 433 & 937 & 1154 & 159 & 259 & 270 & 414 \\
\hline AEX & Netherlands & 4875 & 1184 & 439 & 954 & 1174 & 159 & 266 & 276 & 422 \\
\hline ATX & Austria & 4718 & 1142 & 428 & 924 & 1135 & 155 & 259 & 267 & 407 \\
\hline IBOVESPA & Brazil & 4586 & 1010 & 426 & 931 & 1133 & 154 & 258 & 264 & 409 \\
\hline FTSE Malaysia & Malaysia & 4446 & 879 & 425 & 925 & 1130 & 154 & 259 & 270 & 402 \\
\hline MERVAL & Argentina & 3738 & NA & 428 & 916 & 1144 & 156 & 258 & 264 & 401 \\
\hline BSE & India & 3573 & NA & 396 & 933 & 1139 & 157 & 252 & 262 & 408 \\
\hline JKSE & Indonesia & 3517 & NA & 404 & 894 & 1122 & 153 & 255 & 262 & 401 \\
\hline KOPS & South Korea & 3541 & NA & 399 & 918 & 1135 & 154 & 256 & 272 & 406 \\
\hline TA 100 & Iran & 3028 & NA & 330 & 737 & 966 & 152 & 236 & 243 & 364 \\
\hline TSEC & Taiwan & 3536 & NA & 399 & 918 & 1130 & 157 & 252 & 272 & 407 \\
\hline SHANGHAI & China & 3055 & NA & NA & 781 & 1193 & 160 & 258 & 264 & 398 \\
\hline ATHENS & Greece & 3042 & NA & NA & 782 & 1165 & 159 & 256 & 268 & 411 \\
\hline OMXS & Sweden & 2813 & NA & NA & 517 & 1193 & 159 & 260 & 271 & 412 \\
\hline OSLO & Norway & 2732 & NA & NA & 495 & 1136 & 157 & 260 & 271 & 412 \\
\hline IGBM Madrid & Spain & 2555 & NA & NA & 256 & 1186 & 156 & 263 & 274 & 419 \\
\hline NZX 50 & New Zealand & 1900 & NA & NA & NA & 791 & 156 & 264 & 275 & 414 \\
\hline EURONEX BEL20 & Belgium & 1588 & NA & NA & NA & 641 & 160 & 255 & 135 & 397 \\
\hline
\end{tabular}

Notes: Periods: (1) Pre Asian financial crisis, (2) during the 1997 Asian financial crisis, (3) post Asian crisis: economic recovery, (4) global economic boom, (5) pre global financial crisis (6) during the global financial crisis, (7) post global financial crisis: recovery, (8) Greece debt crisis.

Starting dates: DAX, SSMI SWISS (12/11/1990); IPC (11/11/1991), AEX (11/10/1992), ATX (11/11/1992), IBOVESPA (05/05/1993), FTSE Malaysia (13/12/1993), MERVAL (10/10/1996), BSE, JKSE (07/01/1997), KOPS, TA 100, TSEC (07/07/1997), SHANGHAI, ATHENS (02/01/2000), OMXS, OSLO (02/01/2001), IGBM (02/01/2002), NZX 50 (06/01/2004), EURONEX BEL20 (03/01/2005) 
Appendix B. Periodical standard deviation of stock returns

\begin{tabular}{|c|c|c|c|c|c|c|c|c|c|}
\hline \multicolumn{2}{|c|}{ Global Stock Market Zones } & Period (1) & Period (2) & Period (3) & Period (4) & Period (5) & Period (6) & Period (7) & Period $(8)$ \\
\hline \multicolumn{10}{|c|}{ A: American Markets } \\
\hline S\&P 500 & USA & 0.0387 & 0.0555 & 0.0510 & 0.0320 & 0.0842 & 0.1042 & 0.0713 & 0.0400 \\
\hline NASDAQ IXIC & USA & 0.0088 & 0.0161 & 0.0251 & 0.0104 & 0.0143 & 0.0279 & 0.0123 & 0.0151 \\
\hline DJIA & USA & 0.0074 & 0.0111 & 0.0124 & 0.0080 & 0.0128 & 0.0251 & 0.0115 & 0.0132 \\
\hline IPC & Mexico & 0.0797 & 0.1040 & 0.0803 & 0.0678 & 0.0793 & 0.1097 & 0.0917 & 0.0917 \\
\hline IBOVESPA & Brazil & 0.3265 & 0.1514 & 0.1056 & 0.0879 & 0.1240 & 0.1421 & 0.0952 & 0.0572 \\
\hline MERVAL & Argentina & 0.0530 & 0.1319 & 0.1342 & 0.0840 & 0.1372 & 0.1649 & 0.1423 & 0.0946 \\
\hline \multicolumn{10}{|c|}{ B: Asian and Australian Markets } \\
\hline ASX (AORD) & Australia & 0.0458 & 0.0316 & 0.0262 & 0.0339 & 0.0904 & 0.1012 & 0.0648 & 0.0399 \\
\hline HANG SENG & Hong Kong & 0.0760 & 0.1159 & 0.0782 & 0.0585 & 0.1256 & 0.1396 & 0.1001 & 0.0598 \\
\hline NIKKEI 255 & Japan & 0.0702 & 0.0599 & 0.0701 & 0.0513 & 0.0939 & 0.1154 & 0.0676 & 0.0512 \\
\hline STRAITS & Singapore & 0.0550 & 0.1241 & 0.0761 & 0.0454 & 0.1119 & 0.1358 & 0.0982 & 0.0414 \\
\hline FTSE Malaysia & Malaysia & 0.0834 & 0.1487 & 0.0715 & 0.0414 & 0.0950 & 0.0969 & 0.0714 & 0.0336 \\
\hline BSE & India & NA & 0.0772 & 0.0775 & 0.0889 & 0.1411 & 0.1628 & 0.1223 & 0.0472 \\
\hline JKSE & Indonesia & NA & 0.1439 & 0.0984 & 0.0809 & 0.1589 & 0.1566 & 0.1256 & 0.0624 \\
\hline KOPS & South Korea & NA & 0.1595 & 0.1077 & 0.0660 & 0.1142 & 0.1116 & 0.0720 & 0.0476 \\
\hline TA 100 & Iran & NA & 0.0650 & 0.0740 & 0.0666 & 0.1156 & 0.1298 & 0.0997 & 0.0560 \\
\hline TSEC & Taiwan & NA & 0.0682 & 0.1027 & 0.0499 & 0.1077 & 0.1412 & 0.0980 & 0.0535 \\
\hline SHANGHAI & China & NA & NA & 0.0631 & 0.0840 & 0.1982 & 0.1867 & 0.0999 & 0.0607 \\
\hline NZX 50 & New Zealand & $\mathrm{NA}$ & NA & $\mathrm{NA}$ & 0.0340 & 0.0589 & 0.0693 & 0.0449 & 0.0265 \\
\hline \multicolumn{10}{|c|}{ C: European Markets } \\
\hline FTSE 100 & UK & 0.0402 & 0.0495 & 0.0470 & 0.0299 & 0.0671 & 0.0871 & 0.0648 & 0.0410 \\
\hline $\mathrm{CAC} 40$ & France & 0.0499 & 0.0806 & 0.0701 & 0.0391 & 0.0842 & 0.1008 & 0.0666 & 0.0630 \\
\hline DAX & German & 0.0479 & 0.0822 & 0.0843 & 0.0552 & 0.0896 & 0.1021 & 0.0719 & 0.0635 \\
\hline SSMI SWISS & Switzerland & 0.0521 & 0.0826 & 0.0541 & 0.0436 & 0.0619 & 0.0753 & 0.0588 & 0.0464 \\
\hline AEX & Netherlands & 0.0483 & 0.0823 & 0.0681 & 0.0463 & 0.1118 & 0.1391 & 0.0722 & 0.0507 \\
\hline ATX & Austria & 0.0524 & 0.0758 & 0.0430 & 0.0608 & 0.1432 & 0.1771 & 0.0961 & 0.0882 \\
\hline ATHENS & Greece & NA & NA & 0.3684 & 0.0530 & 0.1453 & 0.1755 & 0.1133 & 0.1529 \\
\hline OMXS & Sweden & NA & NA & 0.0938 & 0.0484 & 0.0893 & 0.1089 & 0.0742 & 0.0552 \\
\hline OSLO & Norway & NA & NA & 0.0722 & 0.0708 & 0.1242 & 0.1555 & 0.0820 & 0.0493 \\
\hline IGBM Madrid & Spain & NA & NA & 0.0661 & 0.0437 & 0.0822 & 0.1024 & 0.0842 & 0.0716 \\
\hline EURONEX BEL20 & Belgium & NA & NA & NA & 0.0341 & 0.1246 & 0.1427 & 0.0865 & 0.0535 \\
\hline
\end{tabular}

Notes: NA - not applicable because no estimation was made due to data limitations. 
Appendix C. Periodical mean of stock returns

\begin{tabular}{|c|c|c|c|c|c|c|c|c|c|}
\hline \multicolumn{2}{|c|}{ Global Stock Market Zones } & Period (1) & Period (2) & Period (3) & Period (4) & Period (5) & Period (6) & Period (7) & Period (8) \\
\hline \multicolumn{10}{|c|}{ A: American Markets } \\
\hline S\&P 500 & USA & 0.0004 & 0.0012 & -0.0004 & 0.0004 & -0.0008 & -0.0018 & 0.0015 & 0.0001 \\
\hline NASDAQ IXIC & USA & 0.0006 & 0.0012 & -0.0006 & 0.0006 & -0.0009 & -0.0014 & 0.0017 & 0.0001 \\
\hline DJIA & USA & 0.0004 & 0.0005 & -0.0002 & 0.0005 & -0.0005 & -0.0017 & 0.0014 & 0.0002 \\
\hline IPC & Mexico & 0.0007 & 0.0008 & 0.0002 & 0.0014 & -0.0003 & -0.0015 & 0.0019 & 0.0002 \\
\hline IBOVESPA & Brazil & 0.0056 & 0.0010 & 0.0001 & 0.0014 & 0.0009 & -0.0016 & 0.0019 & -0.0004 \\
\hline MERVAL & Argentina & NA & -0.0011 & 0.0002 & 0.0012 & -0.0002 & -0.0024 & 0.0029 & 0.00001 \\
\hline \multicolumn{10}{|c|}{ B: Asian and Australian Markets } \\
\hline ASX (AORD) & Australia & 0.0002 & 0.0005 & 0.000001 & 0.0006 & -0.0010 & -0.0015 & 0.0012 & -0.0003 \\
\hline HANG SENG & Hong Kong & 0.0008 & 0.0008 & -0.0002 & 0.0008 & -0.0003 & -0.0019 & 0.0016 & -0.0004 \\
\hline NIKKEI 255 & Japan & -0.0004 & -0.0004 & -0.0007 & 0.0006 & -0.0023 & -0.0016 & 0.0007 & -0.0007 \\
\hline STRAITS & Singapore & 0.0002 & -0.0009 & -0.0001 & 0.0008 & -0.0015 & -0.0020 & 0.0020 & -0.0003 \\
\hline FTSE Malaysia & Malaysia & 0.0002 & -0.0021 & 0.0003 & 0.0007 & -0.0009 & -0.0012 & 0.0016 & 0.0002 \\
\hline BSE & India & NA & 0.0772 & 0.0775 & 0.0889 & 0.1411 & 0.1628 & 0.1223 & 0.0472 \\
\hline JKSE & Indonesia & NA & -0.0005 & 0.0001 & 0.0015 & 0.0001 & -0.0020 & 0.0028 & 0.0005 \\
\hline KOPS & South Korea & NA & 0.0003 & 0.0001 & 0.0010 & -0.0012 & -0.0011 & 0.0014 & 0.0001 \\
\hline TA 100 & Iran & NA & 0.0006 & -0.0001 & 0.0012 & -0.0010 & -0.0015 & 0.0021 & -0.0003 \\
\hline TSEC & Taiwan & NA & -0.0004 & -0.0005 & 0.0007 & -0.0008 & -0.0018 & 0.0016 & -0.0004 \\
\hline SHANGHAI & China & NA & NA & -0.0002 & 0.0010 & -0.0008 & -0.0020 & 0.0007 & -0.0006 \\
\hline NZX 50 & New Zealand & NA & NA & NA & 0.0006 & -0.0012 & -0.0011 & 0.0009 & -0.0001 \\
\hline \multicolumn{10}{|c|}{ C: European Markets } \\
\hline FTSE 100 & UK & 0.0003 & 0.0010 & -0.0005 & 0.0004 & -0.0008 & -0.0014 & 0.0013 & -0.0001 \\
\hline CAC 40 & France & 0.0001 & 0.0014 & -0.0003 & 0.0005 & -0.0014 & -0.0019 & 0.0011 & -0.0006 \\
\hline DAX & German & 0.0004 & 0.0012 & -0.0006 & 0.0008 & -0.0010 & -0.0017 & 0.0015 & -0.0002 \\
\hline SSMI SWISS & Switzerland & 0.0006 & 0.0013 & -0.0005 & 0.0006 & -0.0014 & -0.0014 & 0.0011 & -0.0003 \\
\hline AEX & Netherlands & 0.0007 & 0.0014 & -0.0005 & 0.0004 & -0.0013 & -0.0026 & 0.0017 & -0.0004 \\
\hline ATX & Austria & 0.0004 & 0.0001 & -0.00003 & 0.0012 & -0.0015 & -0.0030 & 0.0017 & -0.0010 \\
\hline ATHENS & Greece & NA & NA & 0.0061 & 0.0009 & -0.0014 & -0.0033 & 0.0004 & -0.0025 \\
\hline OMXS & Sweden & NA & NA & -0.0014 & 0.0008 & -0.0018 & -0.0016 & 0.0019 & -0.0003 \\
\hline OSLO & Norway & NA & NA & -0.0009 & 0.0014 & -0.0012 & -0.0022 & 0.0018 & -0.0001 \\
\hline IGBM Madrid & Spain & NA & NA & -0.0010 & 0.0008 & -0.0009 & -0.0021 & 0.0010 & -0.0007 \\
\hline EURONEX BEL20 & Belgium & NA & NA & NA & 0.0005 & -0.0011 & -0.0029 & 0.0032 & -0.0008 \\
\hline
\end{tabular}

Notes: NA - not applicable because no estimation was made due to data limitations.

\section{Appendix D. Egarch-M estimated with normal and student-t distribution}

\begin{tabular}{lll}
\hline Period & Normal & Student-t \\
\hline $\mathbf{1}$ & HANG SENG, IPC & \\
$\mathbf{2}$ & & DAX, AEX, MERVAL, \\
$\mathbf{3}$ & ATHENS, OSLO & \\
$\mathbf{4}$ & IPC, ATX, OSLO, NXZ 50, & TA 100 \\
$\mathbf{5}$ & FTE 100, CAC 40, MERVAL & BSE, OMXS, SSMI SWISS, IPC, KOPS, EURONEX BEL20, \\
$\mathbf{6}$ & FTE 100, STRAITS, KOPS, TA 100, TSEC, MERVAL, & CAC 40, DAX, OMXS, OSLO \\
$\mathbf{7}$ & STRAITS, OMXS & ATHENS, DAX, SSMI SWISS, ATX, JKSE, TA 100, IGBM \\
$\mathbf{8}$ & S\&P 500, FTE 100, JKSE, KOPS & NIKKEI, SSMI SWISS, DAX \\
\hline
\end{tabular}

\section{Copyrights}

Copyright for this article is retained by the author(s), with first publication rights granted to the journal.

This is an open-access article distributed under the terms and conditions of the Creative Commons Attribution license (http://creativecommons.org/licenses/by/3.0/). 